\title{
Contributions from transport, solid fuel burning and cooking to primary organic aerosols in two UK cities
}

\author{
J. D. Allan ${ }^{1}$, P. I. Williams ${ }^{1}$, W. T. Morgan ${ }^{2}$, C. L. Martin ${ }^{2}$, M. J. Flynn ${ }^{2}$, J. Lee ${ }^{3}$, E. Nemitz ${ }^{4}$, G. J. Phillips ${ }^{4}$, \\ M. W. Gallagher ${ }^{2}$, and H. $\mathrm{Coe}^{2}$ \\ ${ }^{1}$ National Centre for Atmospheric Science, The University of Manchester, Oxford Road, Manchester, M13 9PL, UK \\ ${ }^{2}$ School of Earth, Atmospheric and Environmental Sciences, The University of Manchester, Oxford Road, \\ Manchester, M13 9PL, UK \\ ${ }^{3}$ National Centre for Atmospheric Science, The University of York, Heslington, York, YO10 5DD, UK \\ ${ }^{4}$ Centre for Ecology and Hydrology, Bush Estate, Penicuik, Midlothian, EH26 0QB, UK
}

Received: 1 September 2009 - Published in Atmos. Chem. Phys. Discuss.: 15 September 2009

Revised: 11 December 2009 - Accepted: 8 January 2010 - Published: 22 January 2010

\begin{abstract}
Organic matter frequently represents the single largest fraction of fine particulates in urban environments and yet the exact contributions from different sources and processes remain uncertain, owing in part to its substantial chemical complexity. Positive Matrix Factorisation (PMF) has recently proved to be a powerful tool for the purposes of source attribution and profiling when applied to ambient organic aerosol data from the Aerodyne Aerosol Mass Spectrometer (AMS). Here we present PMF analysis applied to AMS data from UK cities for the first time. Three datasets are analysed, with the focus on objectivity and consistency. The data were collected in London during the Regent's Park and Tower Environmental Experiment (REPARTEE) intensives and Manchester. These occurred during the autumn and wintertime, such that the primary fraction would be prominent. Ambiguities associated with rotationality within sets of potential solutions are explored and the most appropriate solution sets selected based on comparisons with external data. In addition to secondary organic aerosols, three candidate sources of primary organic aerosol (POA) were identified according to mass spectral and diurnal profiles; traffic emissions, cooking and solid fuel burning (for space heating). Traffic represented, on average, $40 \%$ of POA during colder conditions and exhibited a hydrocarbon-like mass spectrum similar to those previously reported. Cooking aerosols represented 34\% of POA and through laboratory work, their profile was matched with that sampled from the heating of seed
\end{abstract}

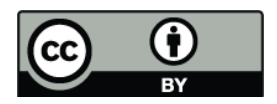

Correspondence to: J. D. Allan (james.allan@manchester.ac.uk) oils, rather than previously-published spectra derived from charbroiling. This suggests that in these locations, oil from frying may have contributed more to the particulate than the meat itself. Solid fuel aerosols represented $26 \%$ of POA during cold weather conditions but were not discernable during the first REPARTEE campaign, when conditions were warmer than the other campaigns. This factor showed features associated with biomass burning and occurred mainly at night. Grid-scale emission factors of the combustion aerosols suitable for use in chemical transport models were derived relative to $\mathrm{CO}$ and $\mathrm{NO}_{\mathrm{x}}$. The traffic aerosols were found to be $20.5 \mu \mathrm{g} \mathrm{m}^{-3} \mathrm{ppm}^{-1}$ relative to CO for Manchester and $31.6 \mu \mathrm{g} \mathrm{m}^{-3} \mathrm{ppm}^{-1}$ relative to $\mathrm{NO}_{\mathrm{x}}$ for London. Solid fuel emissions were derived as $24.7 \mathrm{\mu g} \mathrm{m}^{-3} \mathrm{ppm}^{-1}$ relative to $\mathrm{CO}$ for Manchester. These correspond to mass emission ratios of $0.018,0.026$ (as NO) and 0.021 respectively and are of a similar order to previously published estimates, derived from other regions or using other approaches.

\section{Introduction}

There has long been an association between fine particulate pollution and adverse effects on human health (Pope and Dockery, 2006; Dockery et al., 1993; Fenger, 1999; Künzli et al., 2000). Most official regulation is founded on massbased metrics such as the $\mathrm{PM}_{10}$ and $\mathrm{PM}_{2.5}$ standards (European Union, 2008). However, these particles are known to be composed of a variety of different chemical components, each with their own sources, behaviours and impacts (Pio et al., 2007). Of particular interest are organic aerosols (OA),

Published by Copernicus Publications on behalf of the European Geosciences Union. 
which can constitute a large fraction of the mass of fine particulates and are known to be composed of a highly complex mixture of many tens of thousands of species or more (Hamilton et al., 2004; Jacobson et al., 2000; Saxena and Hildemann, 1996) and potentially have a substantial effect on human health (Mauderly and Chow, 2008). These are known to originate from a variety of different sources, often broadly categorised as either primary or secondary.

While primary aerosols do not necessarily represent the majority of the mass of particulate matter, they are the controlling factor of the ultrafine fraction, i.e. those of less than $100 \mathrm{~nm}$ in size. These are present in very large numbers in urban environments and are potentially very important because they are small enough to penetrate deep into the lungs and additionally, have the potential to transfer into tissues beyond the lungs and cause more physiological damage (Ibald-Mulli et al., 2002; Maudgalya et al., 2008; Kreyling et al., 2006). The transport sector is known to be a major source of primary organic aerosols (POA) in urban environments (Colvile et al., 2001), but others such as cooking (Robinson et al., 2006) and the burning of solid fuels such as biomass (Simoneit, 2002) are also known to be significant in some locations. Further downwind, secondary organic aerosols (SOA) begin to dominate as POA is diluted and SOA is produced (Alfarra et al., 2004; de Gouw et al., 2005; Zhang et al., 2007).

In recent years, the Aerodyne Aerosol Mass Spectrometer (AMS) has proven itself to be a powerful tool in the study of submicron aerosols (Canagaratna et al., 2007; Jayne et al., 2000). As well as being able to quantify the mass concentration of organic matter (Takegawa et al., 2005), information on the functional nature of the organics can be gleaned by inspecting the mass spectra after the inorganic contributions have been removed (Allan et al., 2003a, 2004). The AMS has been shown to generate distinctive spectra from the analysis of organic test aerosols generated from model compositions such as lubricating oil and fulvic acid and the features have been found to be present in ambient and laboratory generated spectra (Canagaratna et al., 2004; McFiggans et al., 2005; Schneider et al., 2006).

Quantitative analysis of organic functionality is possible if factor analysis is employed to analyse the entire AMS organic mass spectrum. The first technique to be widely used was the two-component method introduced by Zhang et al. (2005a), which separated the measured signal as either hydrocarbon-like or oxygenated organic aerosol (HOA or OOA), which can be broadly attributed to POA and SOA respectively in polluted environments. This technique was subsequently modified to a version known as multicomponent analysis (MCA) and 3-component fits have been shown to be applicable to many different polluted environments and able to discern variations in OOA composition (Zhang et al., 2007). More recently, the application of positive matrix factorisation (PMF) (Paatero, 1997) has become widespread. This technique has been successfully applied to other types of atmospheric aerosol data (e.g. Paatero et al.,
2003; Jaeckels et al., 2007; Eatough et al., 2008) and was first used in conjunction with AMS data by Lanz et al. (2007), who showed that in an urban environment (Zurich), the OA quantified by the AMS can be separated into many more sources that go beyond the simple primary and secondary model. In that work, the primary fraction was divided into factors that included HOA, charbroiling and wood burning. In common with Zhang et al. (2007), the secondary fraction was further split into so-called type 1 and type 2 OOA, which exhibited subtle differences in their mass spectra. Type 1 , which is dominated by a peak at $m / z, 44\left(\mathrm{CO}_{2}^{+}\right.$from decarboxylation on the vaporiser surface), has been shown to be typical of highly processed organic aerosols in remote environments (McFiggans et al., 2005). Type 2 had a base peak at $\mathrm{m} / \mathrm{z} 43\left(\mathrm{C}_{2} \mathrm{H}_{3} \mathrm{O}^{+}\right.$and $\left.\mathrm{C}_{3} \mathrm{H}_{7}^{+}\right)$and a greater fraction of signal in minor peaks. It has also showed evidence of being more volatile than type 1 (Huffman et al., 2009a). This is thought to be less oxygenated, less chemically processed secondary material (Jimenez et al., 2009).

The quality of the organic data produced by the AMS has also been improved greatly in recent years by the use of a Tofwerk AG (Thun, Switzerland) orthogonal extraction compact time-of-flight (C-TOF) mass spectrometer (Drewnick et al., 2005), resulting in a much better sensitivity and signalto-noise (Drewnick et al., 2009) that has improved the overall quality of the PMF outputs. More recently, the high resolution time-of-flight (HR-TOF) AMS was developed (DeCarlo et al., 2006). This is capable of operating in a dual reflectron configuration (W mode), which has sufficient mass resolution $\left(m / \Delta m>10^{5}\right)$ to allow the elemental composition of peaks within the mass spectrum to be quantitatively evaluated and estimates made of the chemical functionality of the aerosol, such as the $O / C$ and $H / C$ elemental ratios and the organic mass $(\mathrm{OM})$ to organic carbon $(\mathrm{OC})$ mass ratio (Aiken et al., 2007, 2008). However, the signal to noise ratio is greatly reduced in this mode, so a single reflectron configuration (V mode) is used for producing unit mass resolution data.

With these tools, it is possible to quantitatively attribute various fractions of the organic aerosol burden to different generalised sources. It would be expected that the relative significance of each of these sources would vary according to location and season, due to differences in meteorology and sources, so it is important to compare a number of different datasets. Here, for the first time, we present a PMF attribution study of organic aerosols measured in UK cities, specifically Manchester and London. These are much larger cities compared to Zurich, the subject of Lanz et al. (2007, 2008); the populations within their respective administrative areas were estimated to be 2.6 and 7.6 million in 2007 (Wroth and Wiles, 2009) and if the surrounding areas are included, the overall London agglomeration can be considered a megacity, having a population in excess of 13 million. The focus in this study is the primary fraction, so measurements were performed in autumn and winter, when this fraction will be 
especially prevalent due to reductions in the photochemistry, mixing layer height and emissions of biogenic volatile organic compounds (VOCs). Attempts are made to derive estimates of regional emission factors that could be utilised in regional chemical models.

\section{Experimental}

\subsection{Sites and instrumentation}

The London measurements took place as part of the Regent's Park and Tower Environmental Experiment (REPARTEE). More details regarding the overall experiment and the measurements sites are given in Harrison et al. (2010) and elsewhere in this special issue (e.g. Dall'Osto et al., 2009a). As part of two intensive measurement campaigns (hereafter referred to as REPARTEE 1 and 2), measurements of background aerosol composition were made in Regent's Park in central London. The measurements were conducted in the "Inner Circle" of the park $\left(51.528^{\circ} \mathrm{N},-0.153^{\circ} \mathrm{E}\right)$, which is a $300 \mathrm{~m}$ diameter area surrounded by a park road and at a minimum distance of $500 \mathrm{~m}$ from urban street traffic. Given that the park road is not used intensively by motor vehicles, it is assumed that at this location, the measurements are representative of the urban background atmosphere in an inner city location. The instruments were housed inside a shipping container during REPARTEE 1 and a smaller trailer during REPARTEE 2. Aerosols were sub-sampled from a sampling stack via a $2.5 \mu \mathrm{m}$ cutoff cyclone. REPARTEE 1 took place during October 2006 and REPARTEE 2 during October-November 2007. While both strictly took place during the calendar autumn, the air temperatures were colder during REPARTEE 2 compared to REPARTEE 1 (a mean of 11.6 compared to $15.6^{\circ} \mathrm{C}$ ), and as will be shown, this resulted in changes in the aerosol phenomenology.

In Manchester, a separate set of measurements were also performed at roof level on the Sackville Street Building at The University of Manchester $\left(53.476^{\circ} \mathrm{N},-2.234^{\circ} \mathrm{E}\right)$, which is the same site that has been used in some previous studies (Allan et al., 2003a; Williams et al., 2000). The aerosols were sub-sampled from the flow through a standard $\mathrm{PM}_{10}$ inlet, located on the northeastern side of the building at a height of approximately $35 \mathrm{~m}$, above a street canyon and with no significantly taller buildings in the immediate vicinity. While this site is much closer to the primary sources, it is again assumed to be more (but not perfectly) representative of the urban background air, due to its location above the urban canopy (Longley et al., 2004). Measurements took place during January-February 2007.

During REPARTEE 1 and the Manchester measurements, a compact time-of-flight AMS was used, while in REPARTEE 2 a high resolution time-of-flight AMS was used, alternating between $\mathrm{V}$ and $\mathrm{W}$ modes. During the Manchester sampling, the C-TOF-AMS was run alongside one of the
Table 1. Linear regression outputs comparing the data products of the C-ToF-AMS with the Q-AMS during the Manchester sampling.

\begin{tabular}{lccc}
\hline Species & Slope & Intercept $\left(\mu \mathrm{g} \mathrm{m}^{-3}\right)$ & $r^{2}$ \\
\hline Sulphate & 1.053 & 0.13 & 0.942 \\
Nitrate & 1.049 & 0.12 & 0.971 \\
Organics & 1.130 & 0.11 & 0.968 \\
Ammonium & 0.972 & -0.049 & 0.978 \\
Chloride & 0.883 & -0.062 & 0.977 \\
\hline
\end{tabular}

older quadrupole-based instruments for validation purposes. The linear regression outputs are shown in Table 1 and show errors on the slopes of $13 \%$ or less for all species and $r^{2}$ values of 0.94 or more. The estimated standard deviations of the fitted parameters (based on analysis of residuals) reported by Igor Pro (Version 6.12, Wavemetrics Inc., Portland, OR, USA) were $0.5 \%$ or less for the slopes and $38 \%$ or less for the intercepts. The intercepts of $0.13 \mu \mathrm{g} \mathrm{m}^{-3}$ or less were very small compared to the mass loadings reported during the study. Slight systematic differences between two instruments might be due to subtle differences in the relative ionisation efficiency (RIE) of the different species (Alfarra et al., 2004), however a speculative reason for why the CToF-AMS measured slightly more organics may be due to a difference in the characteristics of the aerodynamic lens. An improvement in the transmission of smaller particles would increase the relative importance of these as the organic fraction tends to dominate particles of these sizes in urban environments (Allan et al., 2003a).

The instruments operated in the standard configuration, taking both mass spectrum (MS) and particle time of flight (pToF) data. The instruments were calibrated using $350 \mathrm{~nm}$ monodisperse ammonium nitrate particles and based on previous experience in urban environments, a collection efficiency (CE) of 0.5 was assumed, in line with the parameterised treatments of Matthew et al. (2008) and Crosier et al. (2007). In the case of REPARTEE 1, this was validated by estimating the ambient volume concentration using the densities reported by Cross et al. (2007) and comparing with that derived using a differential mobility particle sizer (DMPS), as shown in Fig. 1. The volume concentration of the AMS was found to be equal to or less than that of the DMPS. A slightly greater volume as reported by the DMPS would be expected if a fraction of the volume was made up of refractory material such as elemental carbon or dust.

Collocated measurements of carbon monoxide were performed using a fast response fluorescence instrument, (Aero-Laser GmbH, model AL5002, GarmischPartenkirchen, Germany), fitted with a Nafion dryer to remove water vapour. A two-point calibration of the instrument was performed automatically every $6 \mathrm{~h}$, using a primary gas standard containing $21.6 \pm 5 \%$ ppmv $\mathrm{CO}$ in 


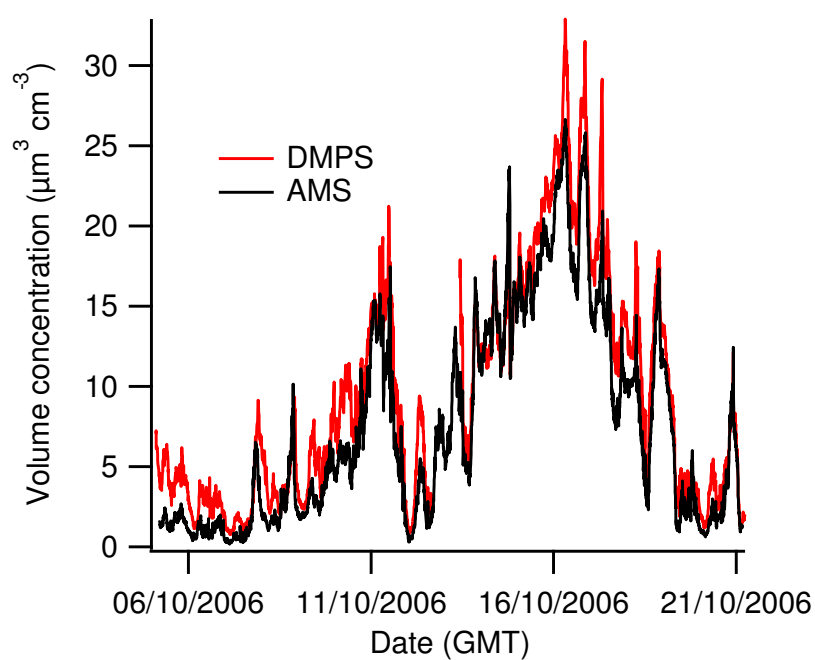

Fig. 1. Volume concentration comparison between the DMPS and AMS during REPARTEE 1. The AMS volume concentrations were estimated assuming densities of 1.27 and $1.77 \mathrm{~g} \mathrm{~cm}^{-3}$ for organics and inorganic contributions respectively.

compressed air (BOC gases, Guildford, Surrey, UK) and catalytically scrubbed (SOFNAFIL) laboratory air. The linearity range of the instrument was $0-100 \mathrm{ppm}$ and was verified through a multi-point span check using a Thermo Fisher Scientific Inc., model 146, gas calibration unit for dilution (Waltham, MA, USA).

During REPARTEE $1, \mathrm{NO}_{\mathrm{x}}$ was measured using a Thermo model $42 \mathrm{C}$ chemiluminescence analyser. The instrument was calibrated using a NO standard in compressed air (BOC) and a gas dilution system (Environics Inc., model 6103 multigas calibrator, Tolland, CT, USA). In all campaigns, optical absorption was measured using a collocated Thermo model 5012 Multi-Angle Absorption Photometer (MAAP) (Petzold et al., 2005), using its factory default mass specific absorption of $6.67 \mathrm{~m}^{2} \mathrm{~g}^{-1}$ to derive equivalent black carbon (EBC) concentrations.

\subsection{Analysis of aerosol mass spectrometer data}

The data analysis was performed using SQUIRREL, the standard ToF-AMS analysis suite developed by the Universities of Manchester and Colorado and Aerodyne Research and hosted electronically at the University of Colorado at Boulder $^{1}$. The high-resolution data was processed to generate quantitative peak areas according to elemental composition using the Peak Integration by Key Analysis (PIKA) software. These data were then used to estimate elemental ratios within the parent molecules using the Analytic Procedure for Elemental Separation (APES) software. These tools were developed and hosted at the University of Colorado.

1 http://cires.colorado.edu/jimenez-group/ToFAMSResources/ ToFSoftware/index.html
The unit mass resolution data from the C-TOF and the $\mathrm{V}$ mode of the HR-TOF were analysed using the "fragmentation table" method described by Allan et al. (2004). This separates signals within the mass spectra according to chemical source by performing weighted subtractions and substitutions based on key identification peaks in the form of matrix operators. For error estimation, the model described by Allan et al. (2003b) was applied to the unit mass resolution data, propagated through the matrixes.

The factorisation of unit mass resolution data was performed using the PMF2 executable version 4.2, as provided by P. Paatero (University of Helsinki), running in robust mode. While it would be possible to perform this analysis on the high resolution data from the REPARTEE 2 campaign, this technique is still in its relative infancy and considered outside the scope of this paper. Additional complications arise during the use of the high resolution data introduced by subtleties and variations in the peak shape and $\mathrm{m} / \mathrm{z}$ calibration fitting. These, in turn, can introduce artefacts in the output of the PMF analysis and uncertainties not accounted for in the standard error model. The PMF Evaluation Toolkit (PET), developed at the University of Colorado and introduced by Ulbrich et al. (2009) was employed. This provided the facility to run the analysis in batches, varying the number of factors, "fpeak" (rotationality) parameter and initiation seed, and the diagnostic tools to evaluate the solutions derived. The default conversion criteria were used, whereby 5 consecutive iterations result in changes of less than 0.5 in $Q$ (the total weighted and squared residual) for the first two iteration stages and 0.3 in the final stage. The maximum cumulative number of iterations was 300 .

In order to make the analysis of the three datasets comparable, the emphasis on the approach used in this work was on consistency and objectivity, rather than seeking to thoroughly evaluate all of the variance within each dataset. The choice of number of factors chosen is covered in detail in the supplementary material: http://www.atmos-chem-phys. net/10/647/2010/acp-10-647-2010-supplement.pdf, but generally speaking, the main criteria were the uniqueness of the factors and numerical stability of the solutions. While the 3and 4-factor solutions presented here may not explain all of the variance within the datasets, higher order solution sets produced were regarded as unreliable and inconsistent results, so were rejected for the purposes of this work.

Only the signals up to $\mathrm{m} / \mathrm{z} 200$ were used, as those of a greater mass were not deemed to be significant due to their low signal-to-noise. The signal at $\mathrm{m} / z, 18\left(\mathrm{H}_{2} \mathrm{O}^{+}\right)$ contains contributions from many sources, so when the organic mass spectrum is extracted using the fragmentation tables, the organic signal at this $\mathrm{m} / \mathrm{z}$ is estimated based on the signal at $\mathrm{m} / z$ $44\left(\mathrm{CO}_{2}^{+}\right)$. This renders the inclusion of the $m / z 18$ peak unsuitable for PMF analysis as it will explicitly covary with the $m / z, 44$ peak, which would cause artificially strong weighting of both peaks. Therefore, the $\mathrm{m} / \mathrm{z}, 18$ peak is removed prior to PMF execution and the 

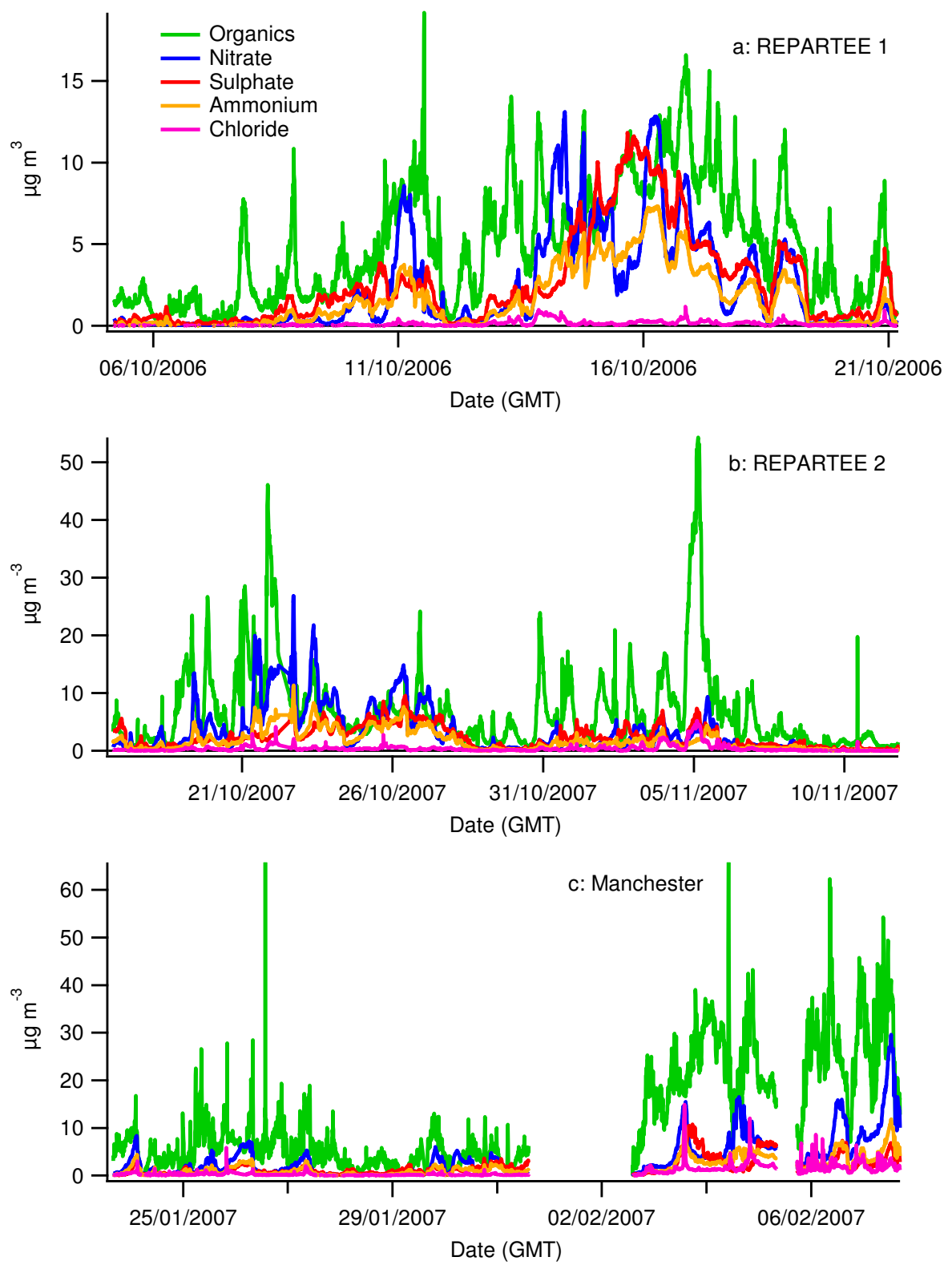

Fig. 2. Reported nonrefractory particulate mass concentrations from AMS measurements during the REPARTEE 1, REPARTEE 2 and Manchester campaigns respectively.

derived mass concentrations are fractionally scaled up according to the derived peak sizes at $\mathrm{m} / \mathrm{z} 44$ (this is an alternative method to the downweighting approach used in other works). At times, certain other peaks were considered problematic (based primarily on inspection of their residuals) and had to be excluded from the analysis and these are mentioned in the results section.

Discrete plumes and spikes can have a negative effect on the applicability of the PMF outputs, so these were manually removed through multiple runs of the analysis. Spikes (caused by local emissions or instrumental glitches) were identified through inspection of the time series of summed residuals and it was found that they typically lasted only one data point, although on occasion up to three consecutive points were removed. The removal of larger plumes was a little more subjective but was done on the basis of identifying parts of the datasets that could be considered atypical of the overall sampling periods. These are described in more detail on a case-by-case basis below or in the supplementary material: http://www.atmos-chem-phys.net/10/647/ 2010/acp-10-647-2010-supplement.pdf. 


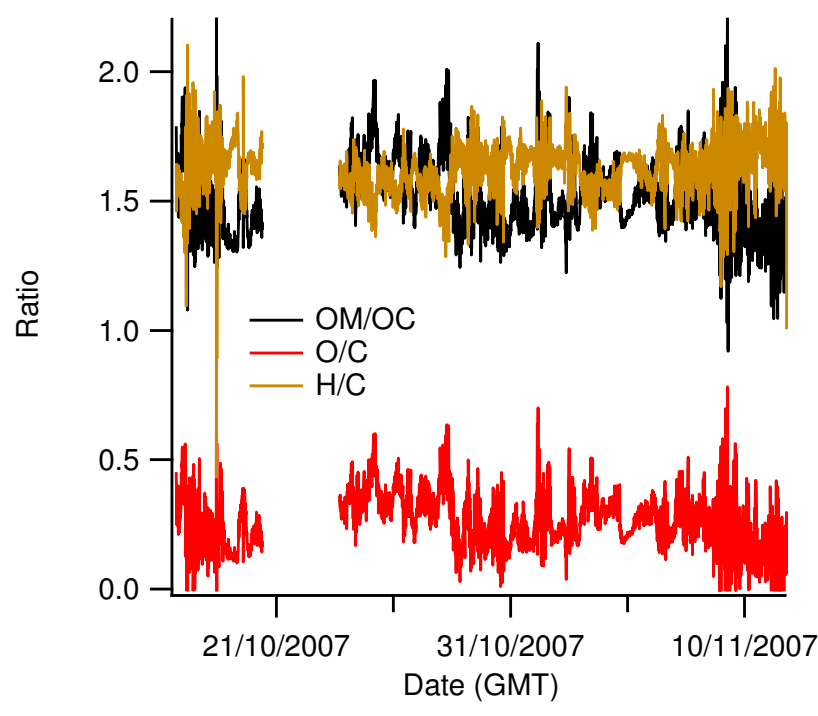

Fig. 3. Elemental ratio analysis of the REPARTEE 2 study.

\section{Results}

\subsection{Basic analysis}

Figure $2 \mathrm{a}$ to $\mathrm{c}$ show the non-refractory mass concentrations encountered during these projects. Generally speaking, organics are the dominant fraction, with contributions from sulphate, nitrate, ammonium and chloride. This fractionation could be considered fairly typical of measurements in urban environments (Zhang et al., 2007). A more detailed analysis of the inorganic aerosol fraction is presented in Nemitz et al. (2010).

The high resolution instrument used during REPARTEE 2 permitted the elemental analysis of the individual organic peaks. For the sake of comparison with the previously published results from Mexico City presented by Aiken et al. (2008), the same calibration factors for $H / C, O / C$ and $N / C$ were used $(0.91,0.75$ and 0.96 respectively) and the results are shown in Fig. 3. The mean $O M / O C$ ratio was found to be 1.53 with a standard deviation of 0.14 . This would correspond to the lower end of the range of values reported from the Mexico City dataset. The $O / C$ ratio was similarly low at $0.27 \pm 0.11$ and the $H / C$ ratio high at $1.62 \pm 0.10$. This is all entirely consistent with the organic aerosol being heavily dominated by primary emissions. The estimated $N / C$ ratio (not shown) was very low at $0.03 \pm 0.01$. There was very little if any evidence to support the presence of organic sulphur, however it is possible that this chemical type would have been detected as inorganic sulphur or non-sulphurous organics by the AMS.

One event that is of note during REPARTEE 2 is the spike around the night of the 4-5 November 2007, which is probably due to Guy Fawkes' night bonfires and fireworks. While 5 November is the traditional date for this event, this fell on a Monday in 2007, so most public displays took place over the preceding weekend. However, it is possible that some events took place on other nights, although these are not as distinct in the data. Similarly high concentrations were observed around Guy Fawkes' night in 2006, following the main REPARTEE 1 period presented here (Nemitz et al., 2010).

The dominance of the organics in the Manchester dataset was particularly evident during the latter part of the measurements, beginning 2 February 2007, when the region came under the influence of an anticyclone and synoptic wind speeds dropped. This resulted in reduced mixing and elevated primary emission concentrations, especially at night when shallow inversions formed over the city. Under these conditions, concentrations typically fell around midday, when the height of the boundary layer rose and the pollutants were diluted through mixing.

For the PMF analysis of REPARTEE 2, the data corresponding to the activity that occurred after midday on 9 November 2007 was removed, as this seemed to cause its own unique factor to be generated in the higher order solutions and large, structured residuals in the lower order solutions (see Sect. 2.1 of the supplementary material: http://www.atmos-chem-phys.net/10/647/ 2010/acp-10-647-2010-supplement.pdf). This would indicate that the reported organics during this period were different to the 4 factors from the rest of the campaign, due to the aerosol having a chemical composition unique to this event. The exact nature of this event was not resolved but irrespective of this, the fact it is clearly distinct from the majority of the campaign renders it unsuitable for analysis. Similarly, the large bonfire peak that occurred between 01:00 to 06:00 on 5 November 2007 was removed as this event was almost certainly unique, although this particular removal did not significantly alter the solution profiles and time series outside of this period. Note that additional firework and bonfire contributions would be expected outside this period, but would be harder to identify.

\subsection{Classification of PMF factors}

In the campaigns presented here, 4-factor solutions were derived for REPARTEE 2 and Manchester and a 3-factor solution for REPARTEE 1. While higher order solutions gave improvements to diagnostics such as $Q / Q_{\text {exp }}$, common features appeared within the time series and profiles of the factors that could be taken as indicative of factor splitting and it was not possible to validate the factors derived with the supporting data available. The solutions chosen also showed a good degree of stability when subjected to bootstrapping analysis, unlike the higher order solutions. These analyses are covered in detail in the supplementary material: http://www.atmos-chem-phys.net/10/647/ 2010/acp-10-647-2010-supplement.pdf. Therefore, in each instance, the results should be seen as the "best estimate" 


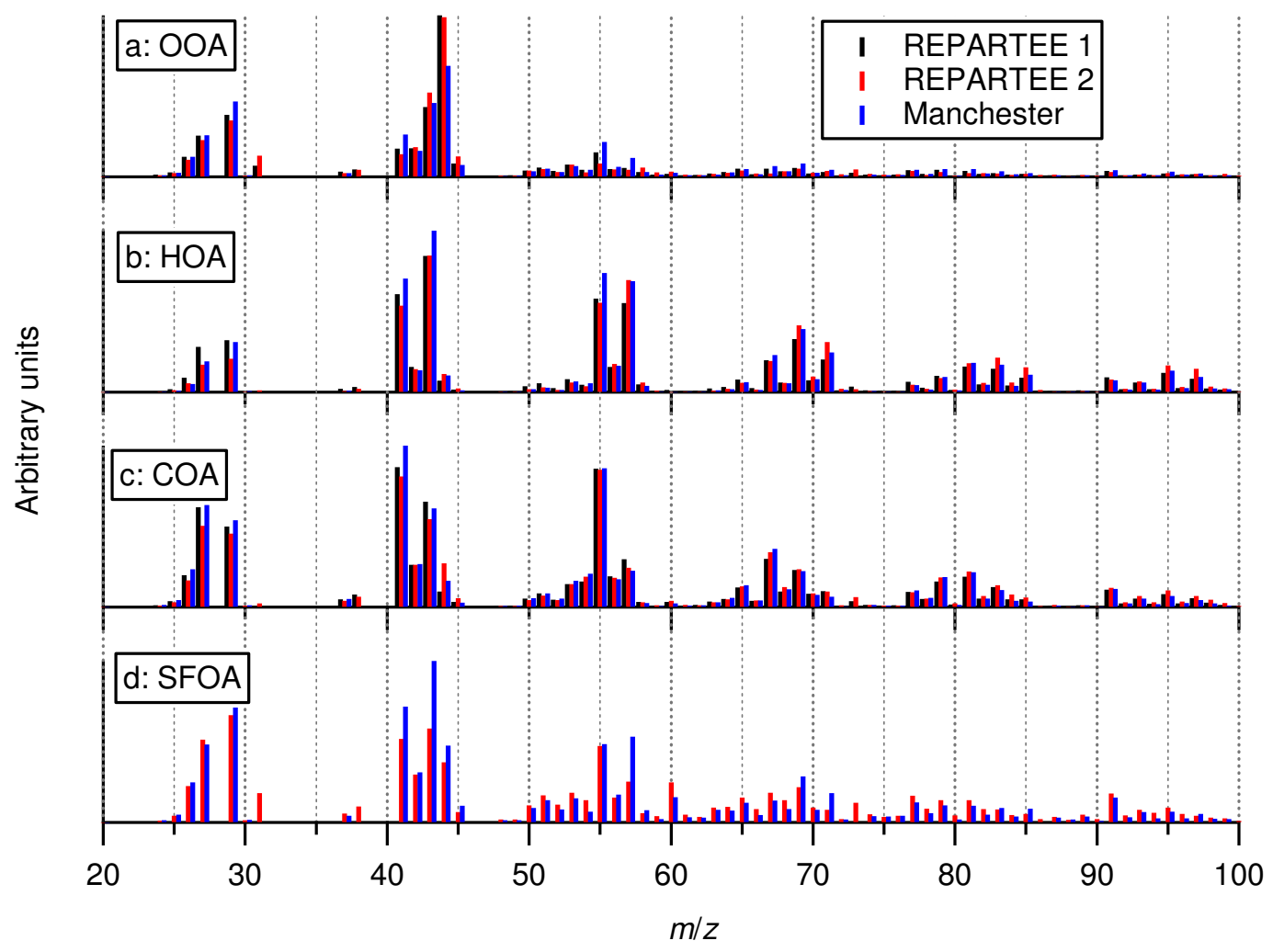

Fig. 4. The averaged mass spectra for the "best estimate" solution sets for each experiment, showing oxygenated organic (OOA), hydrocarbon-like (HOA), cooking (COA) and solid fuel (SFOA) organic aerosol fractions. fpeak=0 was used for REPARTEE 2 and fpeak $=-0.5$ for REPARTEE 1 and Manchester. Only $m / z, 20$ to 100 are shown for clarity.

of a 4 or 3 component assignment, although it is inevitably possible that certain minor fractions and variabilities within fractions are being overlooked.

In the solutions derived, the factor profiles tended to show similarities between the different campaigns and could be classified according to previously published mass spectra (AMS Spectral Database, 2009). The four types and the criteria used to classify these are described below. The example spectra, time series and diurnal profiles from each campaign shown in Figs. 4 to 6 originate from the solutions described at the end of Sect. 3.3. The diurnal profiles are shown using the medians of the data. Note that while GMT $(\mathrm{UTC}+0)$ was used as the time zone for these profiles, the whole of REPARTEE 1 and half of REPARTEE 2 took place during the part of the calendar covered by daylight saving time, meaning local time was BST $(\mathrm{UTC}+1)$. If the diurnal cycles were dominated purely by emissions, it would be more appropriate to use local time for these comparisons. However, as other effects such as boundary layer mixing and photochemistry are expected to play a role, there will also be a dependency on solar time, so for this comparison, there is no universally suitable time zone that should be used.

\subsubsection{Oxygenated Organic Aerosol (OOA)}

These spectra have a strong base peak at $\mathrm{m} / \mathrm{z} 44$ and do not contain significant contributions from marker peaks of other organic aerosol classes such at $m / z 57$ or 60 (Fig. 4a). This spectrum has been widely reported as "type 1" OOA, which is taken to represent well-aged secondary organic aerosols (Lanz et al., 2007; McFiggans et al., 2005; Zhang et al., 2007). This factor does not show a strong diurnal cycle in any of the campaigns (Fig. 6a), which is consistent with a regional source and domination by atmospheric transport rather than local meteorology. A slight dip around midday is seen in all three campaigns, which may be a reflection of mixing occurring as the boundary layer rises in the morning and production in the afternoon. "Type 2" OOA did not feature in any of the solutions derived here; this would indicate that there was not sufficient variance within the OOA fractions (relative to the estimated errors) such that a twofactor model could be reliably applied. That is not to say that "type 2" OOA is not present, rather it is not possible to distinguish it from the "type 1" material and so the fraction is reported as a single factor. 

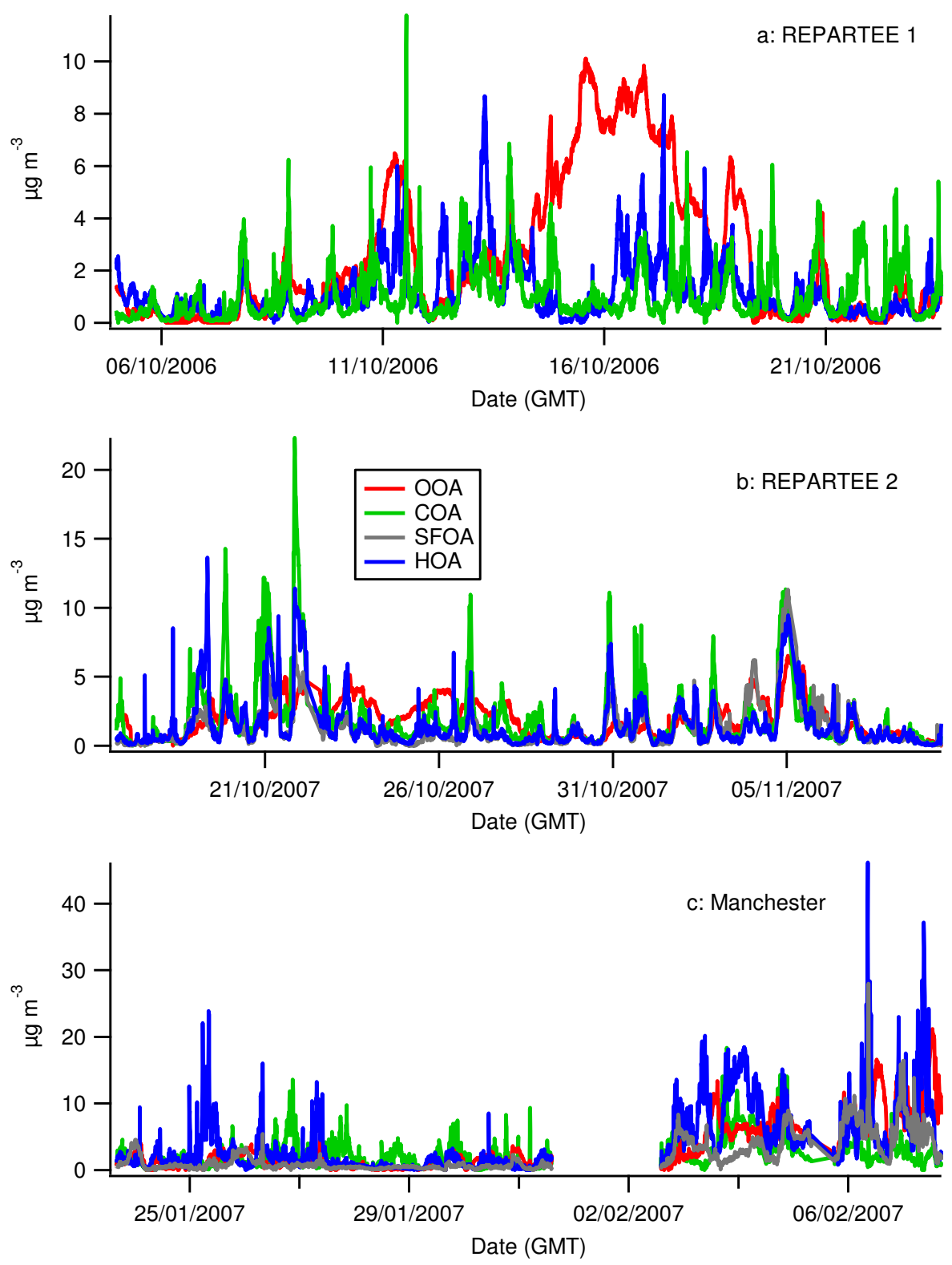

Fig. 5. Time series of the factors from the "best estimate" solutions for REPARTEE 1, REPARTEE 2 and Manchester respectively.

\subsubsection{Hydrocarbon-Like Organic Aerosol (HOA)}

This is again very similar to previously reported spectra, showing characteristic peaks at $\mathrm{m} / \mathrm{z} 41,43,55$ and 57 with little or no signal at 44 and the largest peaks at 43 and 57 (Fig. 4b). This is entirely in keeping with the previously-reported HOA spectra associated with hydrocarbons in vehicle exhaust emissions (Canagaratna et al., 2004; Schneider et al., 2005). In each campaign, the strongest peak in the diurnal cycle occurred in the late morning, which corresponds to the morning rush hour (Fig. 6b). The afternoon rush hour was sometimes present, but was often smaller, presumably due to the elevated boundary layer height and mixing volume typically seen later in the day.

\subsubsection{Cooking Organic Aerosol (COA)}

This has a very similar sequence of peaks to HOA, however unlike the other spectrum, has its largest peaks at $m / z 41$ and 55 (Fig. 4c). This has been previously reported by Lanz et al. (2007) and was associated with charbroiling. This also exhibits a distinctly different diurnal profile to HOA, with a large peak occurring in the late evening and a smaller peak around midday (Fig. 6c). These probably correspond to mealtimes, modulated by the boundary layer height. 


\subsubsection{Solid Fuel Organic Aerosol (SFOA)}

REPARTEE 2 and Manchester showed a factor with a notable signal at $\mathrm{m} / \mathrm{z} 60$ with (in the case of REPARTEE 2) an associated peak at 73 (Fig. 4d), which is usually taken to be due to levoglucosan (in the Manchester dataset, the 73 peak was removed due to excessively large residuals at this $\mathrm{m} / \mathrm{z}$ caused by an unknown interference). A thermal decomposition product of cellulose, levoglucosan is often used as a tracer for biomass burning organic aerosol (BBOA) (Jordan et al., 2006; Simoneit, 2002) and has been seen with the AMS in both ambient and laboratory spectra (Capes et al., 2008; Schneider et al., 2006; Alfarra et al., 2007). Peaks were also observed at $\mathrm{m} / \mathrm{z} 43$ and 55 , with minor peaks at 41 and 57, which is consistent with HOA from combustion. An appreciable signal was also seen at $m / z 44$, which implies a degree of oxygenation that would be consistent with humiclike substances (HULIS) that can be produced by biomass burning (Dinar et al., 2006) and have previously been seen with an AMS during the smouldering phase of wood burning (Weimer et al., 2008). The peak in the diurnal profiles tends to occur in the evening, going into the night (Fig. 6d), which would be consistent with domestic space heating. Wood is commonly used as a space heating fuel in the UK, nationally accounting for $47 \%$ of domestic PM $_{10}$ emissions in 2007 (NAEI, 2009), however other solid fuels such as coal (28\%), peat (14\%) and smokeless fuels (4\%) are also strong contributors and it may be expected that if these are contributing to the organic aerosol produced from this sector, they may covary and also contribute to this factor, warranting the more general classification as "solid fuel" rather than "biomass".

If a 4-factor solution was derived from REPARTEE 1, a factor was sometimes derived that exhibited some of these features. However, the fractional contribution of the $\mathrm{m} / \mathrm{z}, 60$ peak was less than half of those of the SFOA factors derived from other campaigns (0.6 as opposed to 1.4 and 2.2\%), so its assignment as SFOA was questionable. Given the fact that the 4-factor solution also exhibited major instabilities when subjected to bootstrapping analysis (see supplementary material: http://www.atmos-chem-phys.net/10/ 647/2010/acp-10-647-2010-supplement.pdf), the SFOA factor was deemed unreliable in this campaign, so the 3-factor solution, which did not feature a factor with features that could be interpreted as SFOA, was used instead.

\subsection{Rotational ambiguity}

The factors produced by the PMF2 algorithm (in common with many multivariate analyses) are not completely unambiguous and many valid solutions can be derived from a range according to "rotations" of the output vectors within solution space (Paatero et al., 2002). This section deals with evaluating the extent of this ambiguity, its affect on the derived data and choosing the solution most suitable for further analysis from those available.

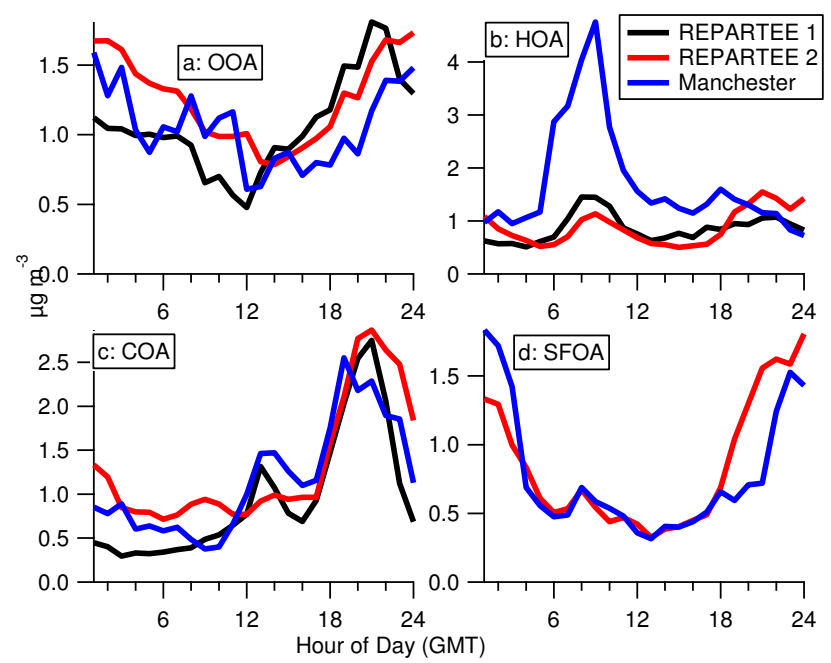

Fig. 6. Median diurnal profiles of the factors from the three campaigns.

\subsubsection{Use of the fpeak parameter}

To facilitate exploration within these solution sets, PMF2 allows for variations of a parameter known as "fpeak", which causes the algorithm to skew the optimisation process (Paatero et al., 2002). This gives alternative solutions that while typically not the most optimal (in terms of $Q$ ), still satisfy the convergence criteria. The setting of a nonzero value often results in the favouring of the numerical separation of the factors in mass spectral space (i.e. the reduction of dot products when comparing the mass spectra) at the expense of separation in time series space (i.e. increased dot products when comparing time series), or vice versa. To explore the solution dependency according to the fpeak parameter, the fractional contributions of the factors were compared after the factors were classified according to the above criteria and shown in Fig. 7a to c.

In each case, only the range of fpeak under which the fit converged is shown. In the case of the REPARTEE campaigns, values less than -1.5 still resulted in successful convergence, but fractional contributions remained roughly constant. The $Q / Q_{\text {exp }}$ values are also shown and consistently minimum at fpeak $=0$, which is the expected behaviour. The values of $Q / Q_{\text {exp }}$ are much greater than would be considered optimal for a perfect characterisation of the data, however as stated before, it would not be possible with the data available to constrain or validate solutions with the greater number of factors needed to reduce $Q$ further. Therefore, the additional contributions to $Q$ could be considered a limitation of the data model and in principle, the inclusion of a model error parameter could reduce $Q / Q_{\exp }$ closer to unity. Previous AMS work (e.g. Lanz et al., 2007; Ulbrich et al., 2009) had achieved more optimal $Q / Q_{\exp }$ values, however during these studies, quadrupole-based instruments were used, so 

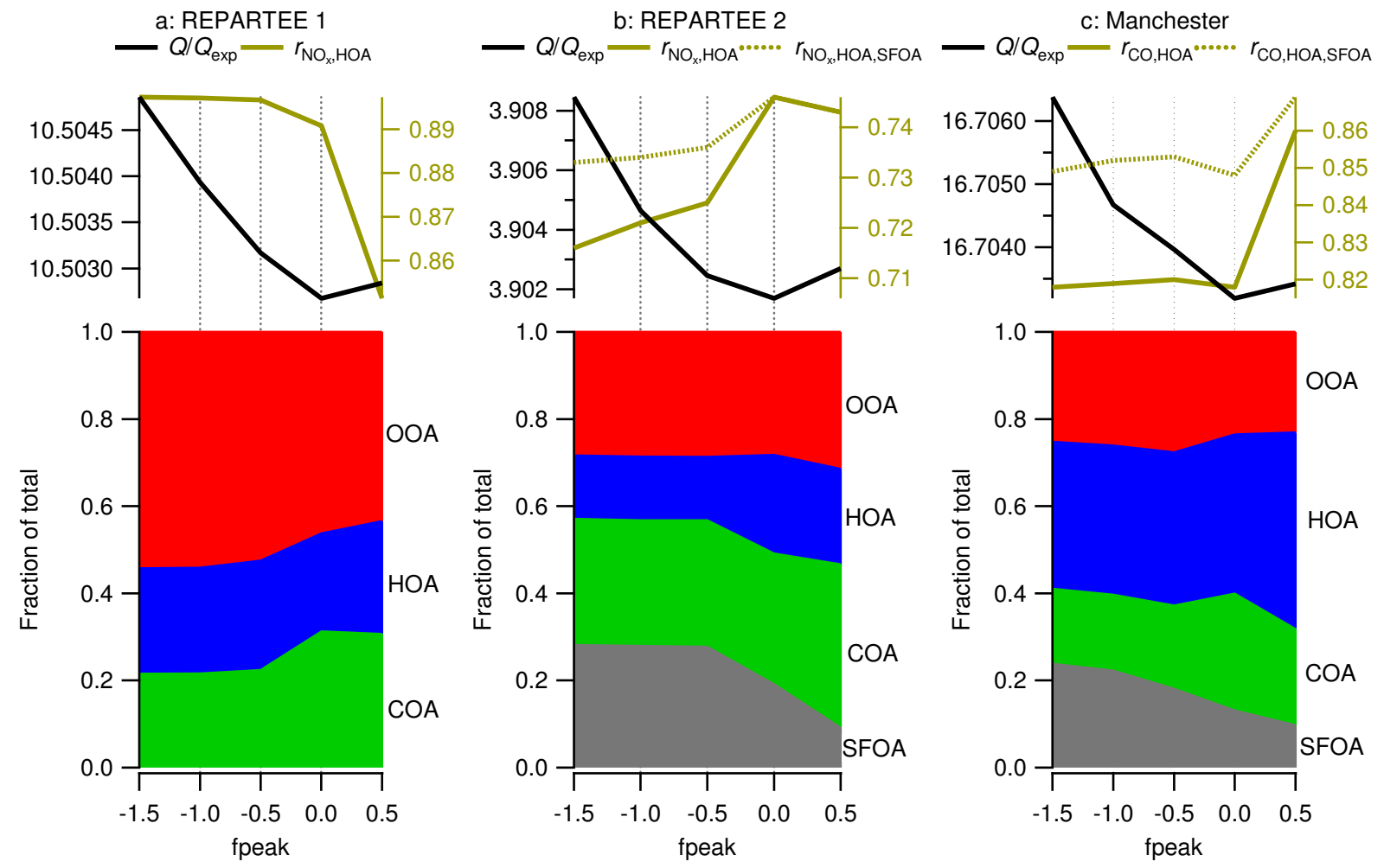

Fig. 7. Variations in the mean mass attributions with varying values of fpeak and Pearson's $r$ values of comparisons of the pyrogenic factors with combustion tracers for (a) REPARTEE 1, (b) REPARTEE 2, (c) Manchester.

the limitation on the number of factors in these cases was the signal-to-noise of the data, not model error.

Upon inspection of the mass spectra, the solutions for positive values of fpeak for REPARTEE 2 and Manchester were discounted, as the SFOA factor began to take on an unrealistic mass spectral profile with many of the characteristic peaks becoming small or zero; in REPARTEE 2, $\mathrm{m} / \mathrm{z}$ 41, 43, 44, 55 and 57 were diminished and in Manchester, $\mathrm{m} / \mathrm{z}$ 55. The mass spectra are shown in Sect. 4 of the supplementary material: http://www.atmos-chem-phys. net/10/647/2010/acp-10-647-2010-supplement.pdf. In both situations, the fractional contribution of SFOA to the total organic mass decreased, indicating that the mass that would otherwise have been contained within these peaks was being assigned to different factors.

Within the other convergent solutions, there was a certain amount of redistribution between the factors. While they could still be assigned according to the criteria above, there were subtle changes in their mass spectral profiles. The derived time series changed little in their qualitative structure, however the magnitude of the specific events varied, which was reflected in variations in the mean contributions to the total mass concentrations. It would seem that many of the convergent solutions could be considered acceptable and without a more definitive and objective method of validation, the range of variability within these solutions presents a level of ambiguity in the data. To investigate the stability of the solutions, bootstrapping analysis was performed, resampling in the time dimension (Ulbrich et al., 2009), and the variability in the solutions was found to be small compared to the rotational ambiguity (see supplementary material: http://www.atmos-chem-phys.net/10/647/ 2010/acp-10-647-2010-supplement.pdf).

\subsubsection{Comparison with external data sources}

In order to further assess how physically meaningful the available solutions are, the factors were compared with inorganic gas phase tracers. In the case of REPARTEE 1, the collocated $\mathrm{NO}_{\mathrm{x}}$ measurement was used and in Manchester, $\mathrm{CO}$ was used. For REPARTEE 2, a collocated measurement was not available, so $\mathrm{NO}_{\mathrm{x}}$ data from an automated London Air Quality Network background monitoring site in North Kensington $\left(51.521^{\circ} \mathrm{N},-0.213^{\circ} \mathrm{E}\right)$ was used. While the distance between the two sites is by no means ideal $(4.3 \mathrm{~km})$, closer network monitoring sites such as Marylebone Road are considered unsuitable due to their proximities to busy roads. It could be expected that there will be general agreement of the temporal trends if not the absolute concentrations of $\mathrm{NO}_{\mathrm{x}}$ at North Kensington and Regent's Park, as they will 
Table 2. Summary of attributed mass fractions based on the "best" solutions. The range of fractions derived from other non-rejected solutions is shown in brackets (those that converged and produced realistic mass spectra).

\begin{tabular}{lccccc}
\hline Campaign & "Best" fpeak & OOA & HOA & COA & SFOA \\
\hline REPARTEE 1 & -0.5 & $53 \%$ & $25 \%$ & $22 \%$ & N/A \\
& & $(43-54 \%)$ & $(22-26 \%)$ & $(22-31 \%)$ & \\
REPARTEE 2 & 0 & $28 \%$ & $23 \%$ & $30 \%$ & $19 \%$ \\
& & $(28-29 \%)$ & $(15-23 \%)$ & $(29-30 \%)$ & $(19-28 \%)$ \\
Manchester & -0.5 & $28 \%$ & $35 \%$ & $19 \%$ & $18 \%$ \\
& & $(24-28 \%)$ & $(33-37 \%)$ & $(17-27 \%)$ & $(13-23 \%)$ \\
\hline
\end{tabular}

both be controlled by the boundary layer mixing and general traffic activity. This assumption is supported by a comparison of $\mathrm{NO}_{\mathrm{x}}$ concentrations measured at the two sites during REPARTEE 1, which yields a Pearson's $r$ value of 0.88 .

Both $\mathrm{NO}_{\mathrm{x}}$ and $\mathrm{CO}$ have been shown to bear a very strong relationship with HOA measured by the AMS as both are emitted by traffic activity (Zhang et al., 2005b). The Pearson's $r$ values derived between these and the HOA factor are shown in Fig. 7a to c. While perfect correlation with gas phase markers would not be expected (due to variations in source functions and different removal processes), it could be expected that some of the gases may also originate from other local combustion sources such as space heating, which would also contribute to SFOA. To address this, instead of linear regression, a bilinear fit was performed using both the HOA and SFOA factors according to the following function:

$$
f(\mathrm{HOA}, \mathrm{SFOA})=A[\mathrm{HOA}]+B[\mathrm{SFOA}]+C
$$

Where $[\mathrm{HOA}]$ and $[\mathrm{SFOA}]$ are the concentrations of the SFOA and HOA derived from the PMF analysis and $A, B$ and $C$ are arbitrary fitting parameters, which are optimised to minimise the squared difference between $f$ (HOA, SFOA) and the combustion tracer (i.e. $\mathrm{NO}_{\mathrm{x}}$ or $\mathrm{CO}$ ). The Pearson's $r$ value between the optimised function and the gas phase mixing ratios are shown in Fig. 7a to $\mathrm{c}$ alongside the value associated with the HOA comparison. The $A$ and $B$ parameters were constrained to be non-negative and some fits resulted in $B$ equalling zero, so the derived $r$ was, in effect, the same as if only HOA had been included in a linear regression.

This approach yielded greater values of $r$ for the CO comparison in Manchester, but did not improve the values of $r$ corresponding to the $\mathrm{NO}_{\mathrm{x}}$ comparison in all of the REPARTEE 2 solutions. This may be because traffic $\mathrm{NO}_{\mathrm{x}}$ dominates over its solid fuel counterpart at this measurement site; if there is a big enough mismatch in the atmospheric lifetimes of SFOA and $\mathrm{NO}_{\mathrm{x}}$ such that their ratio is not conserved and the correlation breaks down over regional scales, so the variance in the $\mathrm{NO}_{\mathrm{x}}$ concentrations will be more representative of the more local source in central London, i.e. traffic.

It could be postulated that there may be some covariance between combustion tracers and COA, given that natural gas is frequently used as a heat source in cooking in the UK, however no discernable improvement to the fits was found when it was included as a third component in Eq. (1). This is most likely because in this environment, emissions from this sector are very small compared to those from traffic and space heating.

For each campaign, a "best estimate" solution was chosen for further analysis. For REPARTEE 1, fpeak $=-0.5$ was used. Generally speaking, the $\mathrm{NO}_{\mathrm{x}}$ correlation improved with decreasing fpeak but the value at -0.5 was considered close to the asymptote, whereas $Q / Q_{\exp }$ began to rise sharply for more negative values. An fpeak of 0 was chosen for REPARTEE 2 as this gave the optimal values for both $Q / Q_{\exp }$ and the $\mathrm{NO}_{\mathrm{x}}$ comparison. For Manchester, -0.5 was used as this gave the best $\mathrm{CO}$ comparison result for a minimal increase in $Q / Q_{\text {exp }}$ relative to fpeak=0. A better $\mathrm{CO}$ correlation was obtained for 0.5 , however this gave an unrealistic SFOA spectrum, as described above. Table 2 gives a summary of the fractional contributions of the factors and the range associated with the rotational ambiguity.

\section{Discussion}

\subsection{Secondary organic aerosols}

PMF analysis on all of the datasets gave mass spectra that could be described as "type 1" OOA using the criteria of previous studies (Jimenez et al., 2009), with a large peak at $\mathrm{m} / \mathrm{z} 44$ and with minor peaks at 43 and 55 . Note that this does not mean that "type 2" OOA was chemically absent in each case, but that there was not enough variation within the OOA during the individual campaigns such that a distinct factor could be reliably discerned. In effect, both factors are combined as a single OOA factor. Assuming that OOA is secondary in nature (some OOA, as discussed below, can arise from biomass burning), the fraction of this to the other factors gives the split between primary and secondary organic aerosols. The POA/SOA values derived here (47 to $72 \%)$ are very high compared to the average of $37 \%$ for urban studies presented by Zhang et al. (2007), however this is not surprising considering the time of year that the campaigns were 
Table 3. The $m / z 44$ fractions and Pearson's $r$ values derived for the different "best estimate" OOA factors derived from the three campaigns. The summed inorganics included sulphate, nitrate, ammonium and chloride.

\begin{tabular}{lccccc}
\hline Campaign & $44 /$ total & $r\left(\mathrm{SO}_{4}\right)$ & $r\left(\mathrm{NO}_{3}\right)$ & $r\left(\mathrm{NH}_{4}\right)$ & $r(\Sigma$ Inorganics $)$ \\
\hline REPARTEE 1 & $16.9 \%$ & 0.905 & 0.752 & 0.903 & 0.897 \\
REPARTEE 2 & $16.6 \%$ & 0.652 & 0.786 & 0.802 & 0.843 \\
Manchester & $12.3 \%$ & 0.673 & 0.900 & 0.919 & 0.926 \\
\hline
\end{tabular}

conducted; in that paper, when comparing summer and winter datasets, both Manchester and Tokyo showed a big wintertime increase in POA/OOA. It also reflects the island location of the UK, which often receives relatively clean background air from the Atlantic.

The results gleaned from REPARTEE 1 contrast with the other two campaigns in that the fractional OOA contributions were slightly larger. At the same time, sulphate concentrations were lower during REPARTEE 1 than during REPARTEE 2 (Nemitz et al., 2010), which may indicate that in terms of airmass history, advection of secondary pollution was less pronounced. Thus a likely reason for the larger OOA during REPARTEE 1 could be the fact that it took place earlier in the year, when there is likely to be more photochemistry taking place and stronger emissions of biogenic VOCs due to the increased temperature (Fehsenfeld et al., 1992). The campaign also showed the greatest 44/total ratio (Table 3), which is a proxy for the level of oxidation in the organics.

Many previous studies have noted correlations between OOA and other aerosol species attributed to secondary sources, notably sulphate and nitrate. This would indicate a similarity in the emissions of precursors and formation of such species (Lanz et al., 2007, 2008; Zhang et al., 2007), which given that these can be photochemical products of anthropogenic emissions, would seem reasonable. Furthermore, a relationship between nitrate and type 2 OOA has sometimes been reported in other studies, with both anticorrelated with ambient temperature. The behaviour with respect to nitrate is due to a temperature and humidity driven partitioning with gas phase ammonia and nitric acid (Morino et al., 2006). It is possible that if a significant fraction of the less-oxidised SOA is semivolatile (Grieshop et al., 2007; Robinson et al., 2007), it could follow a similar modulation related to temperature. These relationships have lead to types 1 and 2 OOA being referred to as "low volatility" (LV-) and "semivolatile" (SV-) OOA respectively (Jimenez et al., 2009).

It is possible that temperature may be modulating the SOA concentrations in REPARTEE 2 and Manchester, as both show a slight dip just after midday in their diurnal profiles. However, no variation within the OOA factors was found to be strong enough to warrant multiple factors for any of the campaigns presented here. Variations in the behaviour of the single OOA factor were noted between campaigns and showed in Table 3. During REPARTEE 1, the greatest cor- relation was found to be with sulphate. In contrast, the OOA in REPARTEE 2 and Manchester were found to have lower levels of oxidation and to have the greatest correlations with the total inorganics, with nitrate showing a better correlation than sulphate. This behaviour was most pronounced in the wintertime Manchester dataset, which had by far the lowest oxidation levels and the reported mass spectrum that bore the closest similarity to type 2 OOA. This behaviour would be consistent with more photochemistry taking place during the REPARTEE 1 campaign, producing a more oxidised SOA on the same timescale as the production of sulphate on regional scales. This is consistent with the evidence supporting regional production reported by Dall'Osto et al. (2009b).

\subsection{Primary combustion emissions}

The observations of HOA related to traffic in both cities is in common with many previous observations in other cities worldwide and the average mass fractions would be considered typical according to the urban studies presented by Zhang et al. (2007). The significantly greater fraction and reduced rotational ambiguity observed in Manchester is probably due to its closer proximity to the sources.

As part of air quality controls, solid fuel burning that produces smoke is legislated against in most metropolitan areas in the UK, which includes most of the Greater London and Greater Manchester areas (Smoke Control Areas, 2009). Smokeless fuels can be used in open fires and seasoned wood can be burned in approved burners. The practice of burning smoking fuels such as wood in open fires is widespread in the rural areas surrounding Manchester. An intensive field study in November 2006 at Holme Moss, a rural site to the southeast of Manchester, showed that locally-produced solid fuel aerosols were a major contributor to the bulk optical absorption properties of the aerosol (Corris, 2008).

During the Manchester sampling, the solid fuel was most prevalent during the stagnant conditions in the latter part of the campaign and very low at other times. Most burning will occur during the late evening and will become trapped within the nocturnal inversion at night, being released when the height of the boundary layer rises during the day. It is possible that the SFOA factor is originating from smokeless burners and fuels within the cities, although it is also possible that burning of smoking fuels was taking place regardless of legislation. While bonfires may be contributing during 
REPARTEE 2 this would have been limited to a few specific nights over the 5 November weekend.

Something that should also be considered is whether the solid fuel emissions are purely limited to factors that contain levoglucosan. Weimer et al. (2008) reported such AMS spectra under laboratory conditions when sampling highefficiency domestic wood burners, the lack of a levoglucosan marker being due to the higher combustion temperatures. The spectra featured an OOA-like peak at $m / z 44$ (probably from biomass burning HULIS), and also featured strong signals at $m / z 55$ and 57, which are more typical HOA. The similarities in the instrument response to the different components mean that there is inherent ambiguity in trying to separate these, manifested in the range of fractionations reported when exploring the rotations.

When comparing the two REPARTEE campaigns, the lack of detectable SFOA during REPARTEE 1 is consistent with the expectation that this would be a weaker source; there would have been less of a requirement for space heating during the warmer temperatures. However, note that it is possible that some SFOA is still present to a smaller degree in the REPARTEE 1 data, however it is not present in sufficient quantities to be resolved by PMF so is instead attributed to other factors. The Aerosol Time-Of-Flight Mass Spectrometer (ATOFMS, TSI, Shoreview MN, USA) deployed by the University of Birmingham (Dall'Osto et al., 2009a, b) also did not record any particle classes with features indicative of biomass burning during REPARTEE 1 (M. Dall'Osto, School of Physics, National University of Ireland, Galway, Ireland, Personal communication, June 2009). Regrettably, this measurement was not available during REPARTEE 2. Inspection of $m / z, 60$ in the averaged spectra would concur with SFOA being less significant, as this represented $0.3 \%$ of the total organic signal in REPARTEE 1 , compared with $0.7 \%$ during REPARTEE 2.

\subsection{Quantitative comparisons with combustion tracers}

In order to budget for the production of POA from traffic within chemical transport models, emission factors can be employed. The most appropriate factors to use are those derived on the scales of the resolution of the simulation so as to eliminate sub-grid processes such as deposition and repartitioning that may alter the perceived factors after the initial emission. As a result, these measurements would lend themselves best to those using kilometre-scale grids. Note that for the purposes of the conclusions reached here, a CE of 0.5 was used, as verified by DMPS closure. However, in a number of previous studies (discussed below) other values have been used. While it is possible that a liquid organic coating on soot particles may mitigate particle bounce (the primary cause of CE suppression), it is also likely that a certain amount of primary material in urban atmospheres will be internally mixed with secondary species deposited between emission and detection (Shiraiwa et al., 2007), causing the CE to revert to that of the overall aerosol. In absence of direct evidence to support the use of a greater value, a CE of 0.5 is used here, in line with the bulk of the aerosol. This resulting caveat is that the reported values may prove to be an overestimate if the "true" $\mathrm{CE}$ is greater.

The most desirable reference to use for the emission factors would be carbon dioxide, as a direct relationship can be made between this and fuel consumption (although it can also be modulated by the biosphere). This usually forms the basis of factor derivation by direct source sampling and flux measurement. However, this is an unsuitable tracer for these atmospheric measurements as its background concentrations are too high. For these measurements, carbon monoxide provides a more suitable tracer, as variations due to regional and local sources are much more discernable over the background. Factors derived relative to this can then be used to estimate OA source functions through comparison with existing carbon monoxide inventory data. Recent independent assessment of the UK emission totals of both $\mathrm{CO}$ and $\mathrm{CO}_{2}$ through country-level boundary layer budget measurements suggested that the UK National Atmospheric Emissions Inventory for these compounds is robust (Polson et al., 2010). $\mathrm{NO}_{\mathrm{x}}$ can also be used for near-field sources in an equivalent manner. This has a much smaller background, but a shorter atmospheric lifetime, so will not be suitable for emissions on regional scales.

A previous analysis using this method by Allan et al. (2003a) used a time series of total organic mass concentration of particles below sizes of $200 \mathrm{~nm}$ in vacuum aerodynamic diameter and through linear regression with gas phase data from a roof-level network monitoring site $0.75 \mathrm{~km}$ away, a POA emission factor of $2.29 \mathrm{\mu g} \mathrm{m}^{-3} \mathrm{ppm}^{-1}$ (at STP) compared to $\mathrm{CO}$ and $21.1 \mu \mathrm{g} \mathrm{m}^{-3} \mathrm{ppm}^{-1}$ compared to $\mathrm{NO}_{\mathrm{x}}$ were derived. These were subsequently revised to 3.74 and $34.2 \mu \mathrm{g} \mathrm{m}^{-3} \mathrm{ppm}^{-1}$ respectively (assuming a CE of 1 ) as quantification techniques improved (Allan, 2004).

The measurements presented here offered a number of improvements of the previous results and an opportunity to quantify the emission factor much more reliably. Because of the improved sensitivity of the instrument and the collocation with the gas measurements, a much improved fit to the data would be expected. By way of comparison, the calculation performed previously by Allan et al. (2003a) was repeated using the new dataset, comparing the mass concentration of organics contained within particles smaller than $200 \mathrm{~nm}$ with the gas phase CO. An increased Pearson's $r$ value was found (0.84, as compared to 0.65 ) and an emission factor of $10.30 \mu \mathrm{g} \mathrm{m}^{-3} \mathrm{ppm}^{-1}$ derived for a CE of 0.5 . This equates to an increase of $37 \%$ over the previous estimate after taking account of the different $C E$ values used. This difference may be due to a change in the overall fleet emission profile in the intervening time, however it may be that there was a systematic error in the previous estimate due to the physical separation in the measurements and resulting differences in their source footprints. 
It is expected that a much more robust evaluation of the emission factor can be derived when using the outputs of the PMF analysis, as this separates the organic fractions more explicitly than simple sizing. Performing a linear regression fit using the "best estimate" HOA data generates an emission factor of $11.5 \mathrm{\mu g} \mathrm{m}^{-3} \mathrm{ppm}^{-1}$ (CE=0.5). However, as shown above, the quality of the fit improves if the SFOA is included and the emission factors of the two fractions are, in effect, the reciprocals of the $A$ and $B$ parameters in Eq. (1). Using this, the emission factors of HOA and SFOA are estimated as 20.5 and $24.7 \mathrm{\mu g} \mathrm{m}^{-3} \mathrm{ppm}^{-1}$ respectively (equivalent to mass emission ratios of 0.018 and 0.021). Somewhat counter-intuitively, the derived emission factor for HOA is greater using this method. Because the diurnal cycles of the two fractions are mismatched, destructive interference occurs between the two patterns. Estimated standard deviations from the fits were 0.3 and $1.0 \mu \mathrm{g} \mathrm{m}^{-3} \mathrm{ppm}^{-1}$ respectively, however the range of possible values arising from the rotational ambiguity are much greater. Values derived for HOA range from 19.4 to $21.6 \mu \mathrm{g} \mathrm{m}^{-3} \mathrm{ppm}^{-1}$ while SFOA varies between 18.0 to $35.7 \mu \mathrm{g} \mathrm{m}^{-3} \mathrm{ppm}^{-1}$.

By comparison, using Q-AMS data from tower-based measurements in Manchester (from the $80 \mathrm{~m}$ tall "Portland Tower" during May 2006) and London (from the $190 \mathrm{~m}$ tall "BT Tower" during REPARTEE 1), Phillips et al. (2010) identified organic aerosol factors with mass spectra that were very similar to those of OOA, $\mathrm{HOA}$ and $\mathrm{COA}$ derived here. However, the split between HOA and COA was less robust, probably owing to the lower signal to noise ratio of the QAMS (compared with the ToF-AMS) and the smaller relative contribution of these factors to the total organic aerosol due to dilution at the higher measurement heights. Thus some of the analysis of fluxes presented by Phillips et al. (2010) was based on a more robust two-component PMF solution. For the BT Tower measurements during REPARTEE 1, based on the two-component PMF split into HOA and OOA, Phillips et al. (2010) derived an HOA emission factor relative to $\mathrm{CO}$ of $13.9 \mathrm{\mu g} \mathrm{m}^{-3} \mathrm{ppm}^{-1}$ from concentration measurements and an emission factor of $27.5 \mu \mathrm{g} \mathrm{m}^{-3} \mathrm{ppm}^{-1}$ from flux measurements, which show a wide spread. It evident that the convolution of a contribution from cooking within the HOA component of the OA would result in an over-estimation of the emission factor derived from the BT tower AMS data. The diurnal cycle in the HOA flux derived by Phillips et al. (2010) peaked at midday and in the evening, which is more similar to the diurnal pattern in the COA factor presented here than in the diurnal cycle in the available traffic activity data. This would be consistent with a significant contribution of COA to the aerosol emissions, but could also reflect the fact that the traffic activity data was not fully representative of the total traffic activity in the flux footprint.

While $\mathrm{CO}_{2}$ background concentrations are too large to quantify the urban increment and thus the ratio of HOA to $\mathrm{CO}_{2}$ concentrations (and thus fuel consumption) directly, urban $\mathrm{CO}_{2}$ emissions could nevertheless be derived from flux measurements on the BT Tower (Helfter et al., 2010), together with fluxes of CO (Phillips et al., 2010). Molar flux ratios averaged over central London of $\mathrm{CO}$ relative to $\mathrm{CO}_{2}$ (during REPARTEE 1) were fairly constant over the day at $8.9 \times 10^{-3}$. If this ratio is applied to the emission factor of $\mathrm{HOA}$ relative to $\mathrm{CO}$ derived from Manchester, an emission factor of $\mathrm{HOA}$ relative to $\mathrm{CO}_{2}$ can be estimated as $0.183 \mu \mathrm{g} \mathrm{m}^{-3} \mathrm{ppm}^{-1}$, which corresponds to a mass emission ratio of $9.3 \times 10^{-5}$.

A similar comparison can be made using the collocated measurements of $\mathrm{NO}_{\mathrm{x}}$ during REPARTEE 1 (the physical separation of the measurements during REPARTEE 2 renders this unsuitable for that campaign). The factor derived is $31.6 \mu \mathrm{g} \mathrm{m}^{-1} \mathrm{ppm}^{-1}$ (a mass emission ratio of 0.026 , assuming $\mathrm{NO}_{\mathrm{x}}$ is emitted as $\mathrm{NO}$ ), which is $53 \%$ less than the CE-equivalent value estimated by Allan (2004). While this could be partly due to an increase in accuracy (as discussed above), it is also possible that this reflects a difference in the fleet emission profiles between the two cities. The range of values obtained by exploring the rotational ambiguity was 26.3 to $31.6 \mu \mathrm{g} \mathrm{m}^{-1} \mathrm{ppm}^{-1}$.

The OM factors derived here are about 2.4 times greater for $\mathrm{CO}$ and $50 \%$ less for $\mathrm{NO}_{\mathrm{x}}$ compared to the CEequivalent values derived from Pittsburgh sampling by Zhang et al. (2005b), which could be a reflection of differences in the fleet emission profiles. Taken as wholes, the USA and $\mathrm{UK}$ are very different in terms of sources of $\mathrm{CO}$ and $\mathrm{NO}_{\mathrm{x}}$ from the transport sector. The breakdowns from recent data from the relevant national inventories (EPA, 2009; NAEI, 2009) are shown in Fig. 8. The majority of CO emissions in both countries originate from petrol engines, although in the USA a large fraction of the total (49\%) is from petrol-driven goods vehicles. A much bigger fraction of UK CO emissions originates from diesel engines (9.4 as opposed to 1.9\%) and within these diesel $\mathrm{CO}$ emissions, a substantially larger fraction is made up of light duty goods vehicles and cars (47 as opposed to $1.8 \%$ ). The contribution to $\mathrm{NO}_{\mathrm{x}}$ emissions from heavy duty diesel is more similar between the two countries (51 and 44\% for the UK and USA respectively), as is that from petrol-driven cars (28 and 24\%). However, in the USA, the majority of the remaining $\mathrm{NO}_{\mathrm{x}}$ emissions originate from petrol-driven goods vehicles whereas in the UK, it mainly originates from diesel-powered cars and light duty goods vehicles. Given that these vehicle types are highly likely to have greatly different $\mathrm{OM}$ emission profiles, this will directly translate to different fleet $O M / C O$ and $O M / N O$ profiles between the two countries. In addition, it is also possible that within these vehicle classifications, differences in engine sizes may also be playing a role. In either case, the values derived here should be considered more representative of the UK urban fleet as a whole.

The $\mathrm{NO}_{\mathrm{x}}$ factor derived here is around 5 times greater than the equivalent derived by Schneider et al. (2008) based on chasing heavy duty diesel vehicles in Germany, although it must be noted that their estimate is a reflection of a specific 
vehicle type and driving conditions rather than a fleet average. It may be that the $O M / N O$ ratio changes for this engine type for urban driving and also the emission factors reported by NAEI (2009) show light duty diesel goods vehicles emit 3.8 times more $\mathrm{PM}_{10}$ relative to $\mathrm{NO}_{\mathrm{x}}$ during equivalent driving conditions when compared with heavy duty equivalents, so when comparing overall city traffic with this, the difference is perhaps not surprising.

Emission factors for solid fuel burning have been found to be highly variable in direct source sampling experiments, with the emission profiles depending on the temperature of the burn, the fuel used and oxygen availability. Khalil and Rasmussen (2003) reported an $O C / C O$ mass emission ratio of 0.0178 for smouldering wood burning, which assuming an $O M / O C$ ratio of 1.6 (Turpin and Lim, 2001), would equate to an organic matter emission factor of $35 \mu \mathrm{g} \mathrm{m}^{-3} \mathrm{ppm}^{-1}$, greater than the value of $24.7 \mu \mathrm{g} \mathrm{m}^{-3} \mathrm{ppm}^{-1}$ derived here, although it must be noted that that work was more representative of wild fires. The simulations of domestic wood burning presented by Alfarra et al. (2007) gave organic emission factors relative to $\mathrm{CO}$ for open burning ranging from 5 to $21.25 \mathrm{\mu g} \mathrm{m}^{-3} \mathrm{ppm}^{-1}$ for the flaming phase and 1.3 to $2.5 \mu \mathrm{g} \mathrm{m}^{-3} \mathrm{ppm}^{-1}$ for the smouldering phase (S. Weimer, Internal Combustion Engines Laboratory, EMPA Materials Science \& Technology, Dübendorf, Switzerland, personal communication, April 2009). Interestingly, the ratio derived for an automatic domestic burner (fuelled with beech chips) was much greater at $106 \mathrm{~g} \mathrm{~m}^{-3} \mathrm{ppm}^{-1}$. Given that the value derived here is an average of burning within the local region which will involve many different types of burners, this agreement seems reasonable.

In all three campaigns, collocated measurements of equivalent black carbon were made and used to conduct a numerical comparison with the combustion aerosols. It is not prudent to optimise a linear combination as was performed with the gas phase tracers, as there is a complex relationship between the mass specific absorption and mixing state (Bond et al., 2006; Fuller et al., 1999). It has been found that a coating of organic material can drastically enhance the reported equivalent black carbon (Lack et al., 2008; Slowik et al., 2007) and as such, only qualitative comparisons can be made without modelling the optical properties of the particles explicitly.

The Pearson's $r$ values comparing the factors with the reported equivalent black carbon is shown in Table 4 . In all campaigns, the closest relationship is found with HOA, which is not unexpected due to the high elemental carbon content of aerosols from the traffic sector (Bond et al., 2004). The next best $r$ value was found with SFOA in REPARTEE 2 but Manchester is slightly different in that a slightly better correlation with OOA is derived in comparison to SFOA. However, much of the variability in that dataset is driven by the transition between the non-stagnant and stagnant conditions. When the analysis is repeated using only the data after 2 February 2007, all of the relationships weaken, but the re-

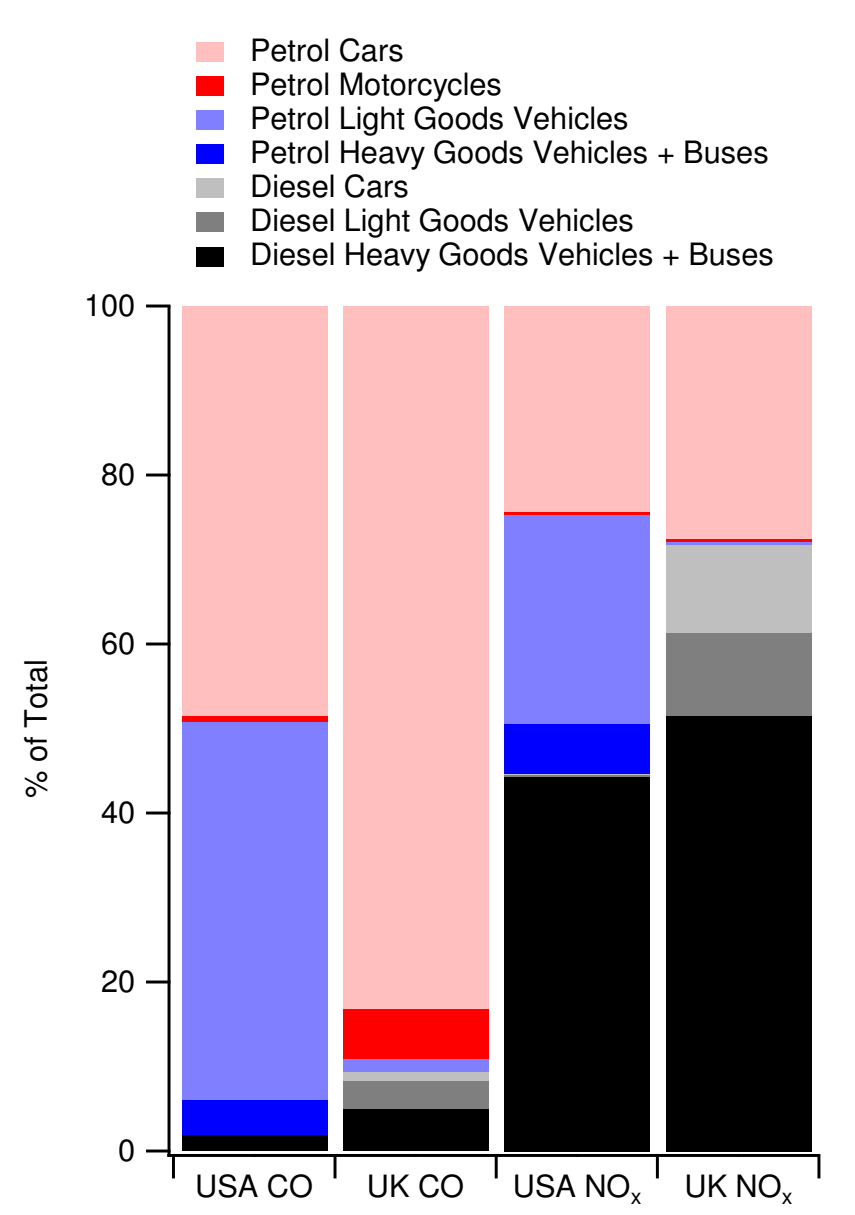

Fig. 8. Percentages of transport $\mathrm{CO}$ and $\mathrm{NO}_{\mathrm{x}}$ for the USA and UK according to vehicle and fuel type. USA data is taken from the 2005 Environmental Protection Agency Atmospheric Emissions Inventory. UK data is taken from the 2006 Department of the Environment, Food and Rural Affairs National Atmospheric Emissions Inventory.

lationship with SFOA becomes stronger than that for OOA, in line with REPARTEE 2.

\subsection{Cooking aerosols}

In all three datasets, a robust factor was derived that can be associated with cooking aerosols, based on the diurnal profile and the similarity of the mass spectral profile to that reported by Lanz et al. (2007). At around 34\%, the fractional contribution to POA is greater than the estimate of a $5-20 \%$ contribution to primary PM for the USA reported by Simon et al. (2008). Cooking is known to release a complex combination of different chemical species, depending on the food being cooked and the method of cooking (Schauer et al., 1999, 2002). Many other sources of these species exist within the atmosphere and they are subject to many transformation processes, making marker-based estimates of sources difficult (Robinson et al., 2006). 
Table 4. Pearson's $r$ values comparing the derived factors to equivalent black carbon concentrations measured using a MAAP. The "Manchester stagnant" is the same calculation only using data after 2 February 2007, when meteorological conditions caused measured concentrations to be much greater.

\begin{tabular}{lcccc}
\hline Campaign & HOA & SFOA & OOA & COA \\
\hline REPARTEE 1 & 0.88 & N/A & 0.61 & 0.27 \\
REPARTEE 2 & 0.91 & 0.74 & 0.46 & 0.70 \\
Manchester & 0.82 & 0.72 & 0.73 & 0.38 \\
Manchester & 0.74 & 0.41 & 0.35 & 0.23 \\
stagnant & & & & \\
\hline
\end{tabular}

As part of general work to help identify factors derived from ambient AMS measurements, various laboratory experiments were conducted by Mohr et al. (2009) and Huffman et al. (2009b), which involved the charbroiling of various foodstuffs such as chicken, fish and processed meat. These produced spectra that bore some similarities with the profiles of the cooking factors derived here in that the $\mathrm{m} / \mathrm{z} 55$ and 41 peaks were very prominent, however there are differences in that the Mohr et al. spectra also had very large peaks at $m / z 43$ (greater than 41) and 57.

While charbroiling is undoubtedly a significant source of particulates it will not be representative of all cooking processes and the prevalence of different practices will vary geographically. One significant alternative source of OA will be oils used during frying; when a body of oil is heated, a fraction will vaporise (after the breakdown of glycerides where present) and subsequently recondense as the air carrying them cools (Schauer et al., 2002; Siegmann and Sattler, 1996). To investigate whether this process may represent a factor in the data presented here, a laboratory experiment was conducted where $200 \mathrm{ml}$ of cooking oil was heated in a metallic container and the air immediately above was sampled continuously with a C-ToF-AMS. The three cooking oils used in this experiment were supermarket brand oils of rapeseed (canola), sunflower and groundnut (peanut).

In each case, OA mass concentrations in excess of $1 \mathrm{mg} \mathrm{m}^{-3}$ were quickly generated after the heat was applied, with a monomodal size distribution peaking below $100 \mathrm{~nm}$ (vacuum aerodynamic), which is qualitatively consistent with the previous experimental work of Yeung and To (2008) and Siegmann and Sattler (1996). This would suggest that the oils were becoming supersaturated in the space immediately above the heated liquid and were nucleating new particles. The mass spectral profiles are shown in Fig. 9. In contrast to the meat cooking spectra previously reported by Mohr et al. (2009), these spectra feature a peak at $\mathrm{m} / \mathrm{z} 41$ that is greater than that at 43 , which while not identical in proportion, is more in keeping with the profiles reported from the ambient data. Some slight variation was noted with oil type, most significantly with $m / z 44$ in the rapeseed oil.

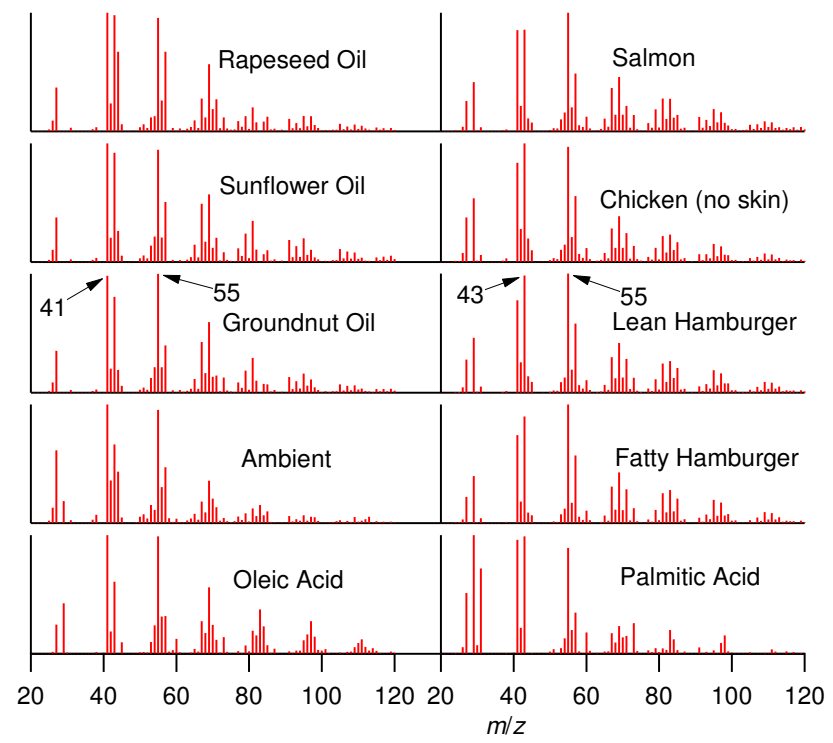

Fig. 9. Mass spectra of various candidates for cooking aerosols. The oil spectra were obtained by sampling aerosols over heated cooking oil baths. The ambient mass spectrum was taken during a period of REPARTEE 2 postulated to be dominated by cooking aerosols. The laboratory-derived spectrum of oleic acid was reported by Katrib et al. (2004) and retrieved via the AMS mass spectral database. The palmitic acid is as reported by Alfarra (2004). The meat cooking spectra are as reported by Mohr et al. (2009).

This would indicate that the ambient cooking aerosols in these studies bear more resemblance to those produced from seed oils used in frying rather than those from meat cooking. When comparing the laboratory and ambient spectra with previously derived laboratory spectra, the laboratory and field spectra show a strong similarity to those reported for oleic (9-octadecenoic) acid by Katrib et al. (2004) and Alfarra (2004). This is a monounsaturated fatty acid present in many plant oils. In contrast, the meat cooking spectra of Mohr et al. (2009) bear a strong resemblance to the spectrum of palmitic (hexadecanoic) acid as reported by Alfarra (2004), a saturated fatty acid. That is not to say that these results indicate the presence of pure-component aerosols, as cooking produces a complex mixture of species in varying proportions which will all be detected by the AMS. Indeed, both oleic and palmitic acids have been shown to be present in both charbroiling and frying emissions (Schauer et al., 1999, 2002). Charbroiling and other cooking activities are known to produce particulates from a very broad range of processes, including fat, char, oil, fuel, etc. Instead, variations in the AMS spectra will be representative of particular groups of organic species within the mixture, which in turn may indicate a prevalence of a particular cooking activity with regards impacts on ambient OA.

Based on the comparisons of ambient AMS spectra with those from laboratory simulations of cooking, it would imply that with regards to the total particulate organics, emissions 
from frying oils are highly significant within ambient measured COA, at least within London and Manchester. Particles of the sizes found in the laboratory study $(<100 \mathrm{~nm})$ could be small enough to penetrate through the extraction systems of commercial kitchens, however the exact sizes of the particles at emission will be entirely dependent on nucleation and coagulation rates, which are difficult to predict.

To evaluate cooking as a factor further, more work is needed to characterise the various cooking sources with an AMS. However, even if sources were to be more comprehensively profiled, it would be difficult to make quantitative estimates of source types based on mass spectral profiles alone, as the emissions will be subject to atmospheric processing that may alter the mass spectral profile. For instance, some species may react heterogeneously with ozone (Zahardis and Petrucci, 2007). The rates of this processes will vary greatly according to the molecular weight and level of saturation of the species. Given the ensemble nature of AMS data, effects such as this would be difficult to model. The most effective way of more accurately constraining the relative prevalence of different cooking types at a given location would be if the ensemble organic data from an AMS could be combined with chemical marker-based data. This would preferably be from an online system such as the Thermal Desorption Aerosol Gas Chromatograph (TAG) (Williams et al., 2006), which would allow the diurnal profiles to be studied.

The relationship between COA and equivalent black carbon (as shown in Sect. 4.3) is positive but weak in all of the campaigns except for REPARTEE 2 and in this instance, its $r$ value is still smaller than those of the combustion sources. While elemental carbon can be associated with charbroiling emissions (Kleeman et al., 2008), this might not be expected with direct emissions from cooking oils during frying. Either way, these particles are not a significant factor in optical absorption in an urban environment compared to the other OA types.

\section{Conclusions}

Presented here is the first PMF attribution study on the organic fraction of urban background AMS data in large European conurbations, studying autumn and wintertime data from two field studies in two UK cities (London and Manchester) covering three intensive measurement campaigns. Given the times of year, the primary fraction is highly significant; at times, the summed primary organic aerosols would represent over half of the $25 \mu \mathrm{g} \mathrm{m}^{-3}$ limit for $\mathrm{PM}_{2.5}$ mass concentration that will be enforced in the UK after 2020 (DEFRA, 2007). Given that the primary particles tend to dominate the ultrafine fraction, these may be a highly significant factor when considering effects of particulates on human health.

Furthermore, this study shows that the primary organic fraction can be split into three factors that can be attributed to known sources, namely transport, cooking and solid fuel burning, based on diurnal profiles and comparisons with previously published mass spectra. While rotational ambiguity introduces a significant amount of uncertainty associated with these assignments, this work indicates that each source is of high significance in UK urban environments; on average, traffic, cooking and solid fuel emissions represent 40,34 and $26 \%$ of POA respectively during the studies in colder conditions. During the campaign in warmer conditions (REPARTEE 1), the solid fuel contribution does not represent enough variance to be reliably discernable as a separate factor using PMF. This is thought to be due to the increased ambient temperatures and associated reduced requirement for space heating.

The combustion factors showed strong relationships with collocated $\mathrm{CO}$ and $\mathrm{NO}_{\mathrm{x}}$ measurements. Kilometre-scale emission factors relative to these gases suitable for use in regional chemical models in conjunction with existing inventory data. The mass emission ratios for traffic-based HOA emissions were derived to be $20.5 \mu \mathrm{g} \mathrm{m}^{-3} \mathrm{ppm}^{-1}$ relative to $\mathrm{CO}$ for Manchester and $31.6 \mu \mathrm{g} \mathrm{m}^{-3} \mathrm{ppm}^{-1}$ relative to $\mathrm{NO}_{\mathrm{x}}$ for London. Solid fuel emissions were derived as $24.7 \mu \mathrm{g} \mathrm{m}^{-3} \mathrm{ppm}^{-1}$ relative to CO for Manchester. These correspond to mass emission ratios of $0.018,0.026$ (as NO) and 0.021 respectively. Exploring PMF rotations gave values in the range of 19.4 to $21.6,26.3$ to 31.6 and 18.0 to $35.7 \mu \mathrm{g} \mathrm{m}^{-3} \mathrm{ppm}^{-1}$ respectively. These values are of a similar order to previously published estimates. Estimates for national emissions can be made by applying mass emission ratios to inventory data if it is assumed that the ratios derived here are representative of the country as a whole. Using 2007 inventory data (NAEI, 2009), the national emission rate of OM from the transport sector is estimated as 13.5 and $11.5 \mathrm{kT}^{-1}$ using the Manchester and London factors respectively. The national OM emission rate from domestic burning can be estimated using the same method as $4.3 \mathrm{kT} \mathrm{y}^{-1}$.

The mass spectral profile of the cooking factor was found to bear a strong resemblance to previously published spectra and its diurnal profile was consistent between the three studies, giving peaks that could be associated with lunch and evening meal time. Comparisons between the derived mass spectral profile with laboratory spectra suggest that a significant source of the organic matter in the cooking aerosols may be from plant oils used in frying rather than the food itself. More work is needed to study these sources further so that their influence on the UK aerosol budget can be evaluated.

This work highlights how much rotational ambiguity there is within the 4-factor solutions. If more accurate assessments of the organic aerosol fractionation are to be gleaned using this method, a greater range of collocated measurements will be required to constrain the solutions, particularly if the organic fraction is to be separated into a greater number of factors. The Multilinear Engine may also be of much use in applying these constraints more systematically and 
basing factor profiles on spectra from laboratory and other field studies (Lanz et al., 2008; Paatero, 1999). However, this will intrinsically be at the expense of objectivity in the analysis. More chemical information could also be gleaned if the technique is applied to the outputs from the analysis of $\mathrm{W}$ mode data from the high resolution AMS datasets. While potentially very powerful, this technique is entirely dependent on the reliable separation of the peaks during data analysis, so extreme care must be taken when fitting and quantifying peaks to avoid artefacts.

Acknowledgements. This work was supported in part by the Natural Environment Research Council (NERC) CityFlux project (ref. NE/B504865/1) and the BOC Foundation. C. L. Martin was supported by a NERC studentship (ref. NER/S/A/2005/13219) and W. T. Morgan was supported by a NERC studentship (ref. NER/S/A/2006/14040) and a CASE sponsorship from Aerodyne Research Inc., Billerica, MA, USA. Network monitoring data was downloaded from the UK Air Quality Archive (http://www.airquality.co.uk). The authors are also grateful to The Royal Parks for facilitating access to the Regent's Park site. Many thanks to Ingrid Ulbrich (University of Colorado at Boulder, USA) for providing and supporting the PMF toolkit, Peter DeCarlo (UC Boulder, now at PSI, Villigen, Switzerland) for the PIKA high resolution toolkit, Allison Aiken (UC Boulder, now at ETH, Zurich, Switzerland) for the APES elemental analysis toolkit and Donna Sueper (UC Boulder and Aerodyne) for the general development and custodianship of the various analysis software. Additional thanks to Manjula Canagaratna (Aerodyne) and Qi Zhang (State University of New York at Albany, USA) for the helpful comments during the preparation of this manuscript.

Edited by: R. M. Harrison

\section{References}

Aiken, A. C., DeCarlo, P. F., and Jimenez, J. L.: Elemental analysis of organic species with electron ionization high-resolution mass spectrometry, Anal. Chem., 79, 8350-8358, 2007.

Aiken, A. C., Decarlo, P. F., Kroll, J. H., Worsnop, D. R., Huffman, J. A., Docherty, K. S., Ulbrich, I. M., Mohr, C., Kimmel, J. R., Sueper, D., Sun, Y., Zhang, Q., Trimborn, A., Northway, M., Ziemann, P. J., Canagaratna, M. R., Onasch, T. B., Alfarra, M. R., Prevot, A. S. H., Dommen, J., Duplissy, J., Metzger, A., Baltensperger, U., and Jimenez, J. L.: O/c and om/oc ratios of primary, secondary, and ambient organic aerosols with high-resolution time-of-flight aerosol mass spectrometry, Environ. Sci. Technol., 42, 44780-4485, 2008.

Alfarra, M. R.: Insights into atmospheric organic aerosols using an aerosol mass spectrometer, $\mathrm{PhD}$ Thesis, Department of Chemical Engineering, UMIST, Manchester, UK, 2004.

Alfarra, M. R., Coe, H., Allan, J. D., Bower, K. N., Boudries, H., Canagaratna, M. R., Jimenez, J. L., Jayne, J. T., Garforth, A., Li, S., and Worsnop, D. R.: Characterization of urban and rural organic particulate in the lower fraser valley using two aerodyne aerosol mass spectrometers, Atmos. Environ., 38, 5745-5758, 2004.
Alfarra, M. R., Prevot, A. S. H., Szidat, S., Sandradewi, J., Weimer, S., Lanz, V. A., Schreiber, D., Mohr, M., and Baltensperger, U.: Identification of the mass spectral signature of organic aerosols from wood burning emissions, Environ. Sci. Technol., 41, 57705777, doi:10.1021/Es062289b, 2007.

Allan, J. D., Alfarra, M. R., Bower, K. N., Williams, P. I., Gallagher, M. W., Jimenez, J. L., McDonald, A. G., Nemitz, E., Canagaratna, M. R., Jayne, J. T., Coe, H., and Worsnop, D. R.: Quantitative sampling using an aerodyne aerosol mass spectrometer -2 . Measurements of fine particulate chemical composition in two UK Cities, J. Geophys. Res.-Atmos., 108, 4091, doi:10.1029/2002JD002359, 2003a.

Allan, J. D., Jimenez, J. L., Williams, P. I., Alfarra, M. R., Bower, K. N., Jayne, J. T., Coe, H., and Worsnop, D. R.: Quantitative sampling using an aerodyne aerosol mass spectrometer -1 . Techniques of data interpretation and error analysis, J. Geophys. Res.Atmos., 108, 4090, doi:10.1029/2002JD002358, 2003b.

Allan, J. D.: An aerosol mass spectrometer: Instrument development, data analysis techniques and quantitative atmospheric particulate measurements, PhD Thesis, Department of Physics, UMIST, Manchester, 2004.

Allan, J. D., Coe, H., Bower, K. N., Alfarra, M. R., Delia, A. E., Jimenez, J. L., Middlebrook, A. M., Drewnick, F., Onasch, T. B., Canagaratna, M. R., Jayne, J. T., and Worsnop, D. R.: A generalised method for the extraction of chemically resolved mass spectra from aerodyne aerosol mass spectrometer data, J. Aerosol. Sci., 35, 909-922, 2004.

Ams spectral database (unit mass resolution): http://cires.colorado. edu/jimenez-group/AMSsd/, last access: July 2009, 2009.

Bond, T. C., Streets, D. G., Yarber, K. F., Nelson, S. M., Woo, J. H., and Klimont, Z.: A technology-based global inventory of black and organic carbon emissions from combustion, J. Geophys. Res.-Atmos., 109, D14203, doi:10.1029/2003jd003697, 2004.

Bond, T. C., Habib, G., and Bergstrom, R. W.: Limitations in the enhancement of visible light absorption due to mixing state, J. Geophys. Res.-Atmos., 111, D20211, doi:10.1029/2006jd007315, 2006.

Canagaratna, M. R., Jayne, J. T., Ghertner, D. A., Herndon, S., Shi, Q., Jimenez, J. L., Silva, P. J., Williams, P., Lanni, T., Drewnick, F., Demerjian, K. L., Kolb, C. E., and Worsnop, D. R.: Chase studies of particulate emissions from in-use new york city vehicles, Aerosol Sci. Tech., 38, 555-573, 2004.

Canagaratna, M. R., Jayne, J. T., Jimenez, J. L., Allan, J. D., Alfarra, M. R., Zhang, Q., Onasch, T. B., Drewnick, F., Coe, H., Middlebrook, A., Delia, A., Williams, L. R., Trimborn, A. M., Northway, M. J., DeCarlo, P. F., Kolb, C. E., Davidovits, P., and Worsnop, D. R.: Chemical and microphysical characterization of ambient aerosols with the aerodyne aerosol mass spectrometer, Mass Spectrom. Rev., 26, 185-222, 2007.

Capes, G., Johnson, B., McFiggans, G., Williams, P. I., Haywood, J., and Coe, H.: Aging of biomass burning aerosols over west africa: Aircraft measurements of chemical composition, microphysical properties, and emission ratios, J. Geophys. Res.Atmos., 113, D00c15, doi:10.1029/2008jd009845, 2008.

Colvile, R. N., Hutchinson, E. J., Mindell, J. S., and Warren, R. F.: The transport sector as a source of air pollution, Atmos. Environ., 35, 1537-1565, 2001.

Corris, B.: Atmospheric aerosol: The link between compostion 
and physical behaviour, $\mathrm{PhD}$ Thesis, School of Earth, Atmospheric and Environmental Sciences, The University of Manchester, Manchester, 2008.

Crosier, J., Allan, J. D., Coe, H., Bower, K. N., Formenti, P., and Williams, P. I.: Chemical composition of summertime aerosol in the po valley (italy), northern adriatic and black sea, Q. J. Roy. Meteor. Soc., 133, 61-75, doi:10.1002/qj.88, 2007.

Cross, E. S., Slowik, J. G., Davidovits, P., Allan, J. D., Worsnop, D. R., Jayne, J. T., Lewis, D. K., Canagaratna, M., and Onasch, T. B.: Laboratory and ambient particle density determinations using light scattering in conjunction with aerosol mass spectrometry, Aerosol Sci. Tech., 41, 343-359, 2007.

Dall'Osto, M., Harrison, R. M., Coe, H., and Williams, P.: Realtime secondary aerosol formation during a fog event in London, Atmos. Chem. Phys., 9, 2459-2469, 2009,

http://www.atmos-chem-phys.net/9/2459/2009/.

Dall'Osto, M., Harrison, R. M., Coe, H., Williams, P. I., and Allan, J. D.: Real time chemical characterization of local and regional nitrate aerosols, Atmos. Chem. Phys., 9, 3709-3720, 2009,

http://www.atmos-chem-phys.net/9/3709/2009/.

de Gouw, J. A., Middlebrook, A. M., Warneke, C., Goldan, P. D., Kuster, W. C., Roberts, J. M., Fehsenfeld, F. C., Worsnop, D. R., Canagaratna, M. R., Pszenny, A. A. P., Keene, W. C., Marchewka, M., Bertman, S. B., and Bates, T. S.: Budget of organic carbon in a polluted atmosphere: Results from the new england air quality study in 2002, J. Geophys. Res.-Atmos., 110, D16305, doi:10.1029/2004JD005623, 2005.

DeCarlo, P. F., Kimmel, J. R., Trimborn, A., Northway, M. J., Jayne, J. T., Aiken, A. C., Gonin, M., Fuhrer, K., Horvath, T., Docherty, K. S., Worsnop, D. R., and Jimenez, J. L.: Field-deployable, high-resolution, time-of-flight aerosol mass spectrometer, Anal. Chem., 78, 8281-8289, 2006.

Department for environment food and rural affairs (defra): The air quality strategy for england, scotland, wales and northern Ireland, http://www.defra.gov.uk/environment/airquality/strategy/ pdf/air-qualitystrategy-vol1.pdf, last access: August 2009, volume 1, cm 7169 nia 61/06-07, 2007.

Dinar, E., Mentel, T. F., and Rudich, Y.: The density of humic acids and humic like substances (HULIS) from fresh and aged wood burning and pollution aerosol particles, Atmos. Chem. Phys., 6, 5213-5224, 2006, http://www.atmos-chem-phys.net/6/5213/2006/.

Dockery, D. W., Pope, C. A., Xu, X. P., Spengler, J. D., Ware, J. H., Fay, M. E., Ferris, B. G., and Speizer, F. E.: An association between air-pollution and mortality in 6 United States cities, New Engl. J. Med., 329, 1753-1759, 1993.

Drewnick, F., Hings, S. S., DeCarlo, P., Jayne, J. T., Gonin, M., Fuhrer, K., Weimer, S., Jimenez, J. L., Demerjian, K. L., Borrmann, S., and Worsnop, D. R.: A new time-of-flight aerosol mass spectrometer (tof-ams)-instrument description and first field deployment, Aerosol Sci. Tech., 39, 637-658, 2005.

Drewnick, F., Hings, S. S., Alfarra, M. R., Prevot, A. S. H., and Borrmann, S.: Aerosol quantification with the aerodyne aerosol mass spectrometer: Detection limits and ionizer background effects, Atmos. Meas. Tech., 2, 33-46, 2009, http://www.atmos-meas-tech.net/2/33/2009/.

Eatough, D. J., Grover, B. D., Woolwine, W. R., Eatough, N. L., Long, R., and Farber, R.: Source apportionment of $1 \mathrm{~h}$ semicontinuous data during the 2005 study of organic aerosols in riverside (soar) using positive matrix factorization, Atmos. Environ., 42, 2706-2719, doi:10.1016/j.atmosenv.2007.07.038, 2008.

European Union: Directive 2008/50/ec of the european parliament and of the council of 21 May 2008 on ambient air quality and cleaner air for europe, Official Journal of the European Union, L152, 2008.

Fehsenfeld, F., Calvert, J., Fall, R., Goldan, P., Guenther, A. B., Hewitt, C. N., Lamb, B., Liu, S., Trainer, M., Westberg, H., and Zimmerman, P.: Emissions of volatile organic compounds from vegetation and the implications for atmospheric chemistry, Global Biogeochem. Cy., 6, 389-430, 1992.

Fenger, J.: Urban air quality, Atmos. Environ., 33, 4877-4900, 1999.

Fuller, K. A., Malm, W. C., and Kreidenweis, S. M.: Effects of mixing on extinction by carbonaceous particles, J. Geophys. Res.Atmos., 104, 15941-15954, 1999.

Grieshop, A. P., Donahue, N. M., and Robinson, A. L.: Is the gas-particle partitioning in alpha-pinene secondary organic aerosol reversible?, Geophys. Res. Lett., 34, L14810, doi:10.1029/2007g1029987, 2007.

Hamilton, J. F., Webb, P. J., Lewis, A. C., Hopkins, J. R., Smith, S., and Davy, P.: Partially oxidised organic components in urban aerosol using GCXGC-TOF/MS, Atmos. Chem. Phys., 4, 12791290, 2004, http://www.atmos-chem-phys.net/4/1279/2004/.

Harrison, R. M., Nemitz, E., Dall'Osto, M., et al.: Atmospheric Chemistry and Physics in the Atmosphere of a Developed Megacity (London): An Overview of the REPARTEE Experiment and its Conclusions, in preparation, 2010.

Helfter, C., Famulari, D., Phillips, G. J., Barlow, J. F., Grimmond, S., Wood, C., and Nemitz, E.: Long-term flux measurements of $\mathrm{CO}_{2}$ above central london, Atmos. Chem. Phys. Discuss., in preparation, 2010.

Huffman, J. A., Docherty, K. S., Aiken, A. C., Cubison, M. J., Ulbrich, I. M., DeCarlo, P. F., Sueper, D., Jayne, J. T., Worsnop, D. R., Ziemann, P. J., and Jimenez, J. L.: Chemically-resolved aerosol volatility measurements from two megacity field studies, Atmos. Chem. Phys., 9, 7161-7182, 2009, http://www.atmos-chem-phys.net/9/7161/2009/.

Huffman, J. A., Docherty, K. S., Mohr, C., Cubison, M. J., Ulbrich, I. M., Ziemann, P. J., Onasch, T. B., and Jimenez, J. L.: Chemically-resolved volatility measurements of organic aerosol from different sources, Environ. Sci. Technol., 43, 5351-5357, doi:10.1021/es803539d, 2009b.

Ibald-Mulli, A., Wichmann, H. E., Kreyling, W., and Peters, A.: Epidemiological evidence on health effects of ultrafine particles, J. Aerosol. Med., 15, 189-201, 2002.

Jacobson, M. C., Hansson, H. C., Noone, K. J., and Charlson, R. J.: Organic atmospheric aerosols: Review and state of the science, Rev. Geophys., 38, 267-294, 2000.

Jaeckels, J. M., Bae, M. S., and Schauer, J. J.: Positive matrix factorization (pmf) analysis of molecular marker measurements to quantify the sources of organic aerosols, Environ. Sci. Technol., 41, 5763-5769, doi:10.1021/Es062536b, 2007.

Jayne, J. T., Leard, D. C., Zhang, X. F., Davidovits, P., Smith, K. A., Kolb, C. E., and Worsnop, D. R.: Development of an aerosol mass spectrometer for size and composition analysis of submicron particles, Aerosol Sci. Tech., 33, 49-70, 2000.

Jimenez, J. L., Canagaratna, M. R., Donahue, N. M., Prevot, A. S. 
H., Zhang, Q., Kroll, J. H., DeCarlo, P. F., Allan, J. D., Coe, H., Ng, N. L., Aiken, A. C., Docherty, K. S., Ulbrich, I. M., Grieshop, A. P., Robinson, A. L., Duplissy, J., Smith, J. D., Wilson, K. R., Lanz, V. A., Hueglin, C., Sun, Y. L., Tian, J., Laaksonen, A., Raatikainen, T., Rautiainen, J., Vaattovaara, P., Ehn, M., Kulmala, M., Tomlinson, J. M., Collins, D. R., Cubison, M. J., Dunlea, J., Huffman, J. A., Onasch, T. B., Alfarra, M. R., Williams, P. I., Bower, K., Kondo, Y., Schneider, J., Drewnick, F., Borrmann, S., Weimer, S., Demerjian, K., Salcedo, D., Cottrell, L., Griffin, R., Takami, A., Miyoshi, T., Hatakeyama, S., Shimono, A., Sun, J. Y., Zhang, Y. M., Dzepina, K., Kimmel, J. R., Sueper, D., Jayne, J. T., Herndon, S. C., Trimborn, A. M., Williams, L. R., Wood, E. C., Middlebrook, A. M., Kolb, C. E., Baltensperger, U., and Worsnop, D. R.: Evolution of organic aerosols in the atmosphere, Science, 326, 1525-1529, doi:10.1126/science.1180353, 2009.

Jordan, T. B., Seen, A. J., and Jacobsen, G. E.: Levoglucosan as an atmospheric tracer for woodsmoke, Atmos. Environ., 40, 53165321, doi:10.1016/j.atmosenv.2006.03.023, 2006.

Katrib, Y., Martin, S. T., Hung, H.-M., Rudich, Y., Zhang, H., Slowik, J. G., Davidovits, P., Jayne, J. T., and Worsnop, D. R.: Products and mechanisms of ozone reactions with oleic acid for aerosol particles having core-shell morphologies, J. Phys. Chem. A, 108, 6686-6695, 2004.

Khalil, M. A. K. and Rasmussen, R. A.: Tracers of wood smoke, Atmos. Environ., 37, 1211-1222, doi:10.1016/S13522310(02)01014-2, 2003.

Kleeman, M. J., Robert, M. A., Riddle, S. G., Fine, P. M., Hays, M. D., Schauer, J. J., and Hannigan, M. P.: Size distribution of trace organic species emitted from biomass combustion and meat charbroiling, Atmos. Environ., 42, 3059-3075, 2008.

Kreyling, W. G., Semmler-Behnke, M., and Moller, W.: Ultrafine particle-lung interactions: Does size matter?, J. Aerosol. Med., 19, 74-83, 2006.

Künzli, N., Kaiser, R., Medina, S., Studnicka, M., Chanel, O., Filliger, P., Herry, M., Horak, F., Puybonnieux-Texier, V., Quénel, P., Schneider, J., Seethaler, R., Vergnaud, J. C., and Sommer, H.: Public-health impact of outdoor and traffic-related air pollution: A european assessment, Lancet, 356, 795-801, 2000.

Lack, D. A., Cappa, C. D., Covert, D. S., Baynard, T., Massoli, P., Sierau, B., Bates, T. S., Quinn, P. K., Lovejoy, E. R., and Ravishankara, A. R.: Bias in filter-based aerosol light absorption measurements due to organic aerosol loading: Evidence from ambient measurements, Aerosol Sci. Tech., 42, 1033-1041, doi:10.1080/02786820802389277, 2008.

Lanz, V. A., Alfarra, M. R., Baltensperger, U., Buchmann, B., Hueglin, C., and Prévôt, A. S. H.: Source apportionment of submicron organic aerosols at an urban site by factor analytical modelling of aerosol mass spectra, Atmos. Chem. Phys., 7, 1503-1522, 2007, http://www.atmos-chem-phys.net/7/1503/2007/.

Lanz, V. A., Alfarra, M. R., Baltensperger, U., Buchmann, B., Hueglin, C., Szidat, S., Wehrli, M. N., Wacker, L., Weimer, S., Caseiro, A., Puxbaum, H., and Prevot, A. S. H.: Source attribution of submicron organic aerosols during wintertime inversions by advanced factor analysis of aerosol mass spectra, Environ. Sci. Technol., 42, 214-220, doi:10.1021/Es0707207, 2008.

Longley, I. D., Gallagher, M. W., Dorsey, J. R., Flynn, M., Bower, K. N., and Allan, J. D.: Street canyon aerosol pollutant transport measurements, Sci. Total Environ., 334, 327-336, 2004.

Matthew, B. M., Middlebrook, A. M., and Onasch, T. B.: Collection efficiencies in an aerodyne aerosol mass spectrometer as a function of particle phase for laboratory generated aerosols, Aerosol Sci. Tech., 42, 884-898, 2008.

Mauderly, J. L. and Chow, J. C.: Health effects of organic aerosols, Inhal. Toxicol., 20, 257-288, doi:10.1080/08958370701866008, 2008.

Maudgalya, T., Genaidy, A., Weckman, G., Shell, R., Karwowski, W., and Wallace, S.: A critical appraisal of epidemiological studies investigating the effects of ultrafine particles on human health, Hum. Factor. Ergon. Man., 18, 358-373, doi:10.1002/Hfm.20115, 2008.

McFiggans, G., Alfarra, M. R., Allan, J., Bower, K., Coe, H., Cubison, M., Topping, D., Williams, P., Decesari, S., Facchini, C., and Fuzzi, S.: Simplification of the representation of the organic component of atmospheric particulates, Faraday Discuss., 130, 341-362, 2005.

Mohr, C., Huffman, J. A., Cubison, M. J., Aiken, A. C., Docherty, K. S., Kimmel, J. R., Ulbrich, I. M., Hannigan, M., and Jimenez, J. L.: Characterization of primary organic aerosol emissions from meat cooking, trash burning, and motor vehicles with highresolution aerosol mass spectrometry and comparison with ambient and chamber observations, Environ. Sci. Technol., 43, 24432449, doi:10.1021/es8011518, 2009.

Morino, Y., Kondo, Y., Takegawa, N., Miyazaki, Y., Kita, K., Komazaki, Y., Fukuda, M., Miyakawa, T., Moteki, N., and Worsnop, D. R.: Partitioning of $\mathrm{HNO}_{3}$ and particulate nitrate over tokyo: Effect of vertical mixing, J. Geophys. Res.-Atmos., 111, D15215, doi:10.1029/2005jd006887, 2006.

National atmospheric emissions inventory (naei): http://www.naei. org.uk/, last access: 4 August, 2009.

Nemitz, E., Phillips, G. J., DiMarco, C. F., Allan, J. D., Barlow, J. F., Coe, H., Dall'Osto, M., Harrison, R. M., and Williams, P. I.: Controls of concentrations, gradients and fluxes of inorganic reactive gases and aerosol components above london, Atmos. Chem. Phys. Discuss., in preparation, 2010.

Paatero, P.: Least squares formulation of robust non-negative factor analysis, Chemometr. Intell. Lab., 37, 23-35, 1997.

Paatero, P.: The multilinear engine - a table-driven, least squares program for solving multilinear problems, including the n-way parallel factor analysis model, J. Comput. Graph. Stat., 8, 854888, 1999.

Paatero, P., Hopke, P. K., Song, X. H., and Ramadan, Z.: Understanding and controlling rotations in factor analytic models, Chemometr. Intell. Lab., 60, 253-264, 2002.

Paatero, P., Hopke, P. K., Hoppenstock, J., and Eberly, S. I.: Advanced factor analysis of spatial distributions of $\mathrm{PM}_{2.5}$ in the eastern united states, Environ. Sci. Technol., 37, 2460-2476, doi:10.1021/Es0261978, 2003.

Petzold, A., Schloesser, H., Sheridan, P. J., Arnott, W. P., Ogren, J. A., and Virkkula, A.: Evaluation of multiangle absorption photometry for measuring aerosol light absorption, Aerosol Sci. Tech., 39, 40-51, doi:10.1080/027868290901945, 2005.

Phillips, G. J., Thomas, R., Famulari, D., Williams, P. I., Crosier, J., Allan, J. D., Coe, H., Gallagher, M., Flynn, M., and Nemitz, E.: Fluxes of submicron aerosol components above three UK cities, Atmos. Chem. Phys. Discuss., in preparation, 2010.

Pio, C. A., Legrand, M., Oliveira, T., Afonso, J., Santos, C., 
Caseiro, A., Fialho, P., Barata, F., Puxbaum, H., SanchezOchoa, A., Kasper-Giebl, A., Gelencser, A., Preunkert, S., and Schock, M.: Climatology of aerosol composition (organic versus inorganic) at nonurban sites on a west-east transect across europe, J. Geophys. Res.-Atmos., 112, D23s02, doi:10.1029/2006jd008038, 2007.

Polson, D., Fowler, D., Nemitz, E., Skiba, U., McDonald, A., Famulari, D., DiMarco, C. F., Simmons, I., Weston, K., Purvis, R. M., Coe, H., Manning, A. J., and Webster, H.: Boundary-layerbudget measurements of greenhouse gas emissions at the country scale, Q. J. Roy. Meteor. Soc., in press, 2010.

Pope, C. A. and Dockery, D. W.: Health effects of fine particulate air pollution: Lines that connect, J. Air Waste Manage., 56, 709742, 2006.

Robinson, A. L., Subramanian, R., Donahue, N. M., BernardoBricker, A., and Rogge, W. F.: Source apportionment of molecular markers and organic aerosol, 3. Food cooking emissions, Environ. Sci. Technol., 40, 7820-7827, doi:10.1021/Es060781p, 2006.

Robinson, A. L., Donahue, N. M., Shrivastava, M. K., Weitkamp, E. A., Sage, A. M., Grieshop, A. P., Lane, T. E., Pierce, J. R., and Pandis, S. N.: Rethinking organic aerosols: Semivolatile emissions and photochemical aging, Science, 315, 1259-1262, doi:10.1126/science.1133061, 2007.

Saxena, P. and Hildemann, L. M.: Water-soluble organics in atmospheric particles: A critical review of the literature and application of thermodynamics to identify candidate compounds, J. Atmos. Chem., 24, 57-109, 1996.

Schauer, J. J., Kleeman, M. J., Cass, G. R., and Simoneit, B. R. T.: Measurement of emissions from air pollution sources, 1. C1 through C29 organic compounds from meat charbroiling, Environ. Sci. Technol., 33, 1566-1577, 1999.

Schauer, J. J., Kleeman, M. J., Cass, G. R., and Simoneit, B. R. T.: Measurement of emissions from air pollution sources, 4. C-1C-27 organic compounds from cooking with seed oils, Environ. Sci. Technol., 36, 567-575, doi:10.1021/es002053m, 2002.

Schneider, J., Hock, N., Weimer, S., and Borrmann, S.: Nucleation particles in diesel exhaust: Composition inferred from in situ mass spectrometric analysis, Environ. Sci. Technol., 39, 61536161, 2005.

Schneider, J., Weimer, S., Drewnick, F., Borrmann, S., Helas, G., Gwaze, P., Schmid, O., Andreae, M. O., and Kirchner, U.: Mass spectrometric analysis and aerodynamic properties of various types of combustion-related aerosol particles, Int. J. Mass Spectrom., 258, 37-49, doi:10.1016/j.ijms.2006.07.008, 2006.

Schneider, J., Kirchner, U., Borrmann, S., Vogt, R., and Scheer, V.: In situ measurements of particle number concentration, chemically resolved size distributions and black carbon content of traffic-related emissions on german motorways, rural roads and in city traffic, Atmos. Environ., 42, 4257-4268, 2008.

Shiraiwa, M., Kondo, Y., Moteki, N., Takegawa, N., Miyazaki, Y., and Blake, D. R.: Evolution of mixing state of black carbon in polluted air from Tokyo, Geophys. Res. Lett., 34, L16803, doi:10.1029/2007g1029819, 2007.

Siegmann, K. and Sattler, K.: Aerosol from hot cooking oil, a possible health hazard, J. Aerosol. Sci., 27, S493-S494, 1996.

Simon, H., Allen, D. T., and Wittig, A. E.: Fine particulate matter emissions inventories: Comparison's of emissions estimates with observations from recent field programs, J. Air Waste Manage.,
58, 320-343, doi:10.3155/1047-3289.58.2.320, 2008.

Simoneit, B. R. T.: Biomass burning - a review of organic tracers for smoke from incomplete combustion, Appl. Geochem., 17, 129-162, 2002.

Slowik, J. G., Cross, E. S., Han, J. H., Davidovits, P., Onasch, T. B., Jayne, J. T., Williams, L. R., Canagaratna, M. R., Worsnop, D. R., Chakrabarty, R. K., Moosmuller, H., Arnott, W. P., Schwarz, J. P., Gao, R. S., Fahey, D. W., Kok, G. L., and Petzold, A.: An inter-comparison of instruments measuring black carbon content of soot particles, Aerosol Sci. Technol., 41, 295-314, 2007.

Smoke control areas: http://www.uksmokecontrolareas.co.uk/, last access: 6 April, 2009.

Takegawa, N., Miyazaki, Y., Kondo, Y., Komazaki, Y., Miyakawa, T., Jimenez, J. L., Jayne, J. T., Worsnop, D. R., Allan, J. D., and Weber, R. J.: Characterization of an aerodyne aerosol mass spectrometer (ams): Intercomparison with other aerosol instruments, Aerosol Sci. Tech., 39, 760-770, 2005.

Turpin, B. J. and Lim, H. J.: Species contributions to pm2.5 mass concentrations: Revisiting common assumptions for estimating organic mass, Aerosol Sci. Tech., 35, 602-610, 2001.

Ulbrich, I. M., Canagaratna, M. R., Zhang, Q., Worsnop, D. R., and Jimenez, J. L.: Interpretation of organic components from Positive Matrix Factorization of aerosol mass spectrometric data, Atmos. Chem. Phys., 9, 2891-2918, 2009,

http://www.atmos-chem-phys.net/9/2891/2009/.

US environmental protection agency technology transfer network clearinghouse for inventories and emissions factors (chief): http: //www.epa.gov/ttn/chief/index.html, last access: 4 August, 2009.

Weimer, S., Alfarra, M. R., Schreiber, D., Mohr, M., Prevot, A. S. H., and Baltensperger, U.: Organic aerosol mass spectral signatures from wood-burning emissions: Influence of burning conditions and wood type, J. Geophys. Res.-Atmos., 113, D10304, doi:10.1029/2007jd009309, 2008.

Williams, B. J., Goldstein, A. H., Kreisberg, N. M., and Hering, S. V.: An in-situ instrument for speciated organic composition of atmospheric aerosols: Thermal desorption aerosol gc/ms-fid (tag), Aerosol Sci. Tech., 40, 627-638, 2006.

Wroth, C. and Wiles, A.: Population and vital statistics by area of usual residence in the United Kingdom, 2007, Office for National Statistics, Newport, UK, series vs no 34, ppi no 30, 2009.

Yeung, L. L. and To, W. M.: Size distributions of the aerosols emitted from commercial cooking processes, Indoor Built Environ., 17, 220-229, doi:10.1177/1420326x08092043, 2008.

Zahardis, J. and Petrucci, G. A.: The oleic acid-ozone heterogeneous reaction system: products, kinetics, secondary chemistry, and atmospheric implications of a model system - a review, Atmos. Chem. Phys., 7, 1237-1274, 2007.

Zhang, Q., Alfarra, M. R., Worsnop, D. R., Allan, J. D., Coe, H., Canagaratna, M. R., and Jimenez, J. L.: Deconvolution and quantification of hydrocarbon-like and oxygenated organic aerosols based on aerosol mass spectrometry, Environ. Sci. Technol., 39, 4938-4952, 2005a.

Zhang, Q., Worsnop, D. R., Canagaratna, M. R., and Jimenez, J. L.: Hydrocarbon-like and oxygenated organic aerosols in Pittsburgh: insights into sources and processes of organic aerosols, Atmos. Chem. Phys., 5, 3289-3311, 2005, http://www.atmos-chem-phys.net/5/3289/2005/. 
Zhang, Q., Jimenez, J. L., Canagaratna, M. R., Allan, J. D., Coe, H., Ulbrich, I., Alfarra, M. R., Takami, A., Middlebrook, A. M., Sun, Y. L., Dzepina, K., Dunlea, E., Docherty, K., DeCarlo, P. F., Salcedo, D., Onasch, T., Jayne, J. T., Miyoshi, T., Shimono, A., Hatakeyama, S., Takegawa, N., Kondo, Y., Schneider, J., Drewnick, F., Borrmann, S., Weimer, S., Demerjian, K., Williams, P., Bower, K., Bahreini, R., Cottrell, L., Griffin, R. J., Rautiainen, J., Sun, J. Y., Zhang, Y. M., and Worsnop, D. R.: Ubiquity and dominance of oxygenated species in organic aerosols in anthropogenically-influenced Northern Hemisphere midlatitudes, Geophys. Res. Lett., 34, L13801, doi:10.1029/2007GL029979, 2007. 